By

Mahbuba Khanam

B. Sc. (Civil Engineering), Bangladesh University of Engineering and Technology, 1997. Graduate Diploma (Information Science), University of New South Wales, Sydney, Australia, 2003.

\author{
A project \\ Presented to Ryerson University \\ In partial fulfillment of the \\ Requirements for the degree of \\ Master in Engineering \\ In the Program of \\ Civil Engineering
}

Toronto, Ontario, Canada, January 2007

(C) Mahbuba Khanam. 
UMI Number: EC53436

\section{INFORMATION TO USERS}

The quality of this reproduction is dependent upon the quality of the copy submitted. Broken or indistinct print, colored or poor quality illustrations and photographs, print bleed-through, substandard margins, and improper alignment can adversely affect reproduction.

In the unlikely event that the author did not send a complete manuscript and there are missing pages, these will be noted. Also, if unauthorized copyright material had to be removed, a note will indicate the deletion.

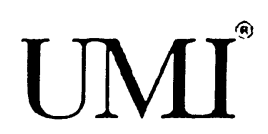

UMI Microform EC53436

Copyright 2009 by ProQuest LLC

All rights reserved. This microform edition is protected against unauthorized copying under Title 17, United States Code.

ProQuest LLC

789 East Eisenhower Parkway

P.O. Box 1346

Ann Arbor, MI 48106-1346 


\section{Author's Declaration}

I hereby declare that I am the sole author of this project report.

I authorize Ryerson University to lend this report to other institutions or individuals for the purpose of scholarly research.

$$
\mu
$$

Name

I further authorize Ryerson University to reproduce this report by photocopying or by other means, in total or in part, at the request of other institutions or individuals for the purpose of scholarly research. 


\section{Borrower's Page}

Ryerson University requires the name, signature of all persons using or photocopying this report. Please sign below and give address and date.

\begin{tabular}{|c|c|c|c|}
\hline Name & Signature & Address & Date \\
\hline & & & \\
\hline & & & \\
\hline & & & \\
\hline & & & \\
\hline & & & \\
\hline & & & \\
\hline & & & \\
\hline & & & \\
\hline & & & \\
\hline & & & \\
\hline & & & \\
\hline & & & \\
\hline & & & \\
\hline & & & \\
\hline & & & \\
\hline & & & \\
\hline & & & \\
\hline & & & \\
\hline & & & \\
\hline & & & \\
\hline & & & \\
\hline & & & \\
\hline & & & \\
\hline & & & \\
\hline & & & \\
\hline & & & \\
\hline & & & \\
\hline & & & \\
\hline & & & \\
\hline & & & \\
\hline & & & \\
\hline
\end{tabular}




\title{
MODELING OF METHANE GAS GENERATION AND EMISSIONS FROM LANDFILLS
}

\author{
By \\ Mahbuba Khanam \\ Master in Civil Engineering (MEng), Ryerson University, Toronto, Canada, 2007.
}

\begin{abstract}
This study was carried out to develop a model capable of predicting the generation and potential emission of methane gas into the environment. Ryerson Landfill Gas Model (RLFGM) was developed using the IPCC tier two model (revised guidelines), the most recent national assessment model (Brown et. al. 1999) from UK and the model developed from DEFRA, UK. This report outlines the findings of the study and its recommendations. The study was performed on detailed characterization of solid waste as RDO, MDO and SDO and by dividing these waste components into nine waste fractions. The waste fractions are described by the percentage of moisture content of the fraction, the proportion of cellulose and hemi-cellulose, and the percentage of the degradability of the cellulose and hemi-cellulose fraction. Methane generating potential $\left(\mathrm{L}_{0}\right)$ was calculated from $\mathrm{DOC}$ and $\mathrm{DOC}_{\mathrm{F}}$ value. The three methane generation rate constants $(\mathrm{k})$ were used. Methane oxidation, methane correction factor, percentage of methane gas recovery, percentage of methane content in landfill gas were assumed based on comprehensive literature review. After the verification of the output of the RLFGM model with the LandGEM model it was found that the model is producing similar type of output graph as the LandGEM model but the rate of emissions of methane gas into the environment is lower in RLFGM model. It has been concluded that RLFGM model gives the realistic output with respect to individual landfill sites, taking into account of specific waste streams and deposition rates.
\end{abstract}




\section{Acknowledgements}

First and foremost, I wish to express my sincere gratitude to Dr. Mostafa Warith, Department of Civil Engineering, Ryerson University, Toronto, Canada, my project supervisor for providing me with a great research opportunity and giving me time to time guideline and supervision to develop the model.

I would like to also extend sincere thanks to the Environment Agency UK, the Department of Environment Food and Rural Affairs (DEFRA) UK, IPCC (The Intergovernmental Panel on Climate Change), USA for their useful information to develop the model. Thanks to United States Environmental Protection Agency (US EPA) for providing me opportunity to use the landfill gas emission model (LandGEM) for the purpose of the verification of RLFGM model. 


\section{TABLE OF CONTENTS}

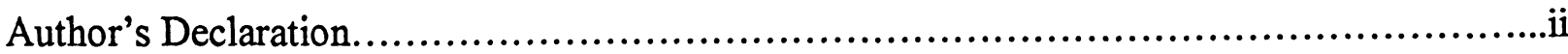

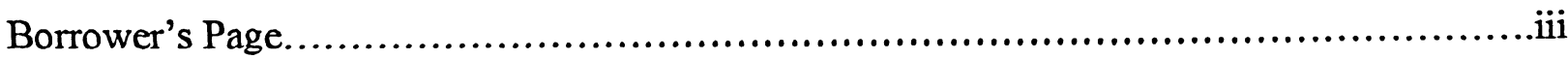

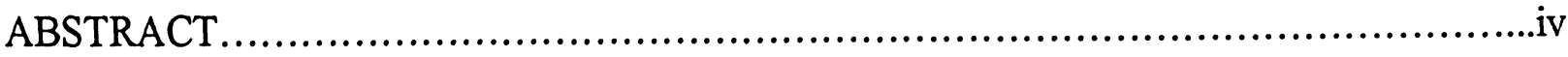

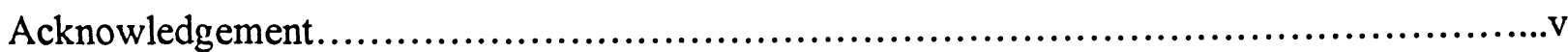

LIST OF ACRONYMS ................................................................ vii

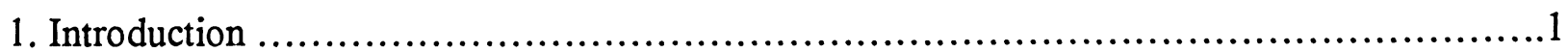

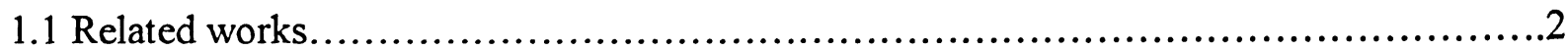

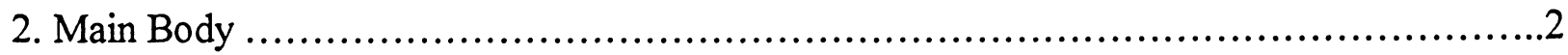

2.1 RLFGM - Ryerson Landfill Gas Model ..........................................2

2.2 Limitations of the model ..........................................................

2.3 Waste category used in the simulation of RLFGM model ..............................

2.4 RLFGM conceptual model .........................................................4

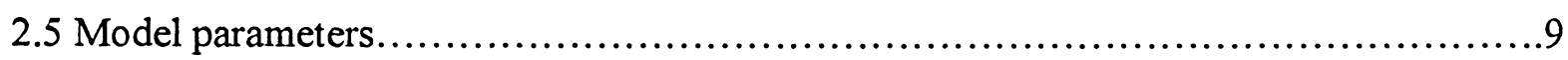

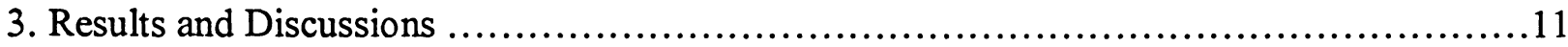

4. Data inputs and model verification................................................. 14

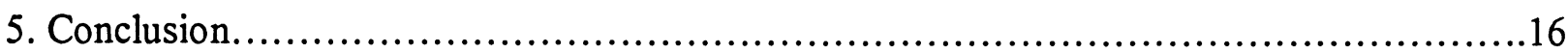

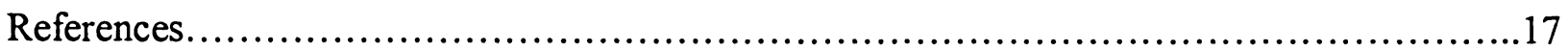

\section{Appendix A}

\section{LIST OF TABLES}

Table 1 Summary of the landfill gas generation and emission models from United States

Environmental Protection Agency (US EPA).

Table 2 Summary of the landfill gas generation and emission models from the Intergovernmental

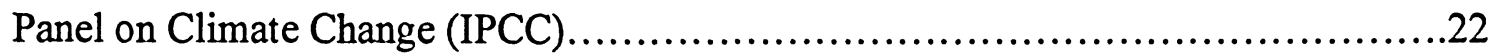

Table 3 Summary of the landfill gas generation and emission models from Environment Agency, UK and model developed for Department of Environment Food and Rural Affairs

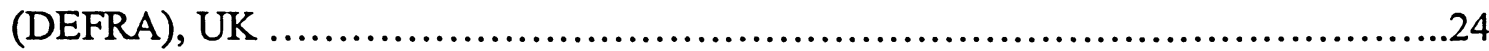

Table 4 Other models summary on landfill gas generation and emissions....................27

Table 5 Different types of waste categories used for the analysis of the RLFGM model..........30

Table 6 MSW waste (Mt) used in the simulation of RLFGM model..........................30

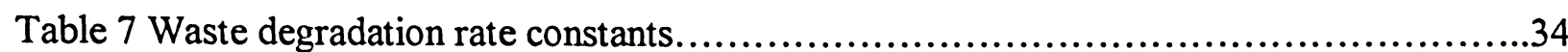

Table 8 SWDS (Solid Waste Disposal Sites) classification and methane correction factors......34 
Table 9 Typical landfill gas compositions at methanogenic phase...........................34

Table 10 Calculated DOC(x).DOC $\mathrm{F}$ values based on data input in Table $6 \ldots \ldots \ldots \ldots \ldots \ldots \ldots \ldots . . .35$

Table 11 Sample output of RLFGM model implementation for methane gas generation potential . .36

Table 12 Parameters from RLFGM model used for the simulation of the LandGEM model for the purpose of model verification................................................36

Table 13 Methane gas emission rates from RLFGM model and LandGEM model................36

Table 14 Comparison between RLFGM and LandGEM model..............................37

\section{LIST OF FIGURES}

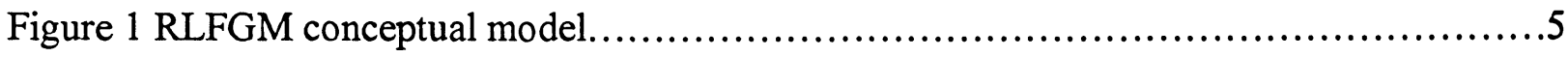

Figure 2 Analysis of methane gas generation rate $(\mathrm{Gg} / \mathrm{yr})$ from landfill.......................12

Figure 3 Analysis of methane gas emission rate $(\mathrm{Gg} / \mathrm{yr})$ from landfill........................13

Figure 4 Comparing methane gas generation and emission rate $(\mathrm{Gg} / \mathrm{yr})$ from landfill...........13

Figure 5 LandGEM model output for methane gas emission from landfill......................15 


\section{LIST OF ACRONYMS}

DEFRA Department of Environment Food and Rural Affairs

DOC Degradable Organic Carbon

$D_{F} \quad$ Fraction Dissimilated

EPA Environmental Protection Agency

FOD First Order Decay

GHG Greenhouse Gas

IPCC Intergovernmental Panel on Climate Change

LandGEM Landfill Gas Emission Model

LFG Landfill Gas

LQM Land Quality Management

MDO Moderately Degradable Organic

MSW Municipal Solid Waste

RDO Rapidly Degradable Organic

RLFGM Ryerson Landfill Gas Model

SDO Slowly Degradable Organic

SWDS Solid Waste Disposal Sites 


\section{Introduction}

The latest estimation of climate change found that the temperature of the earth has been increased by $0.6^{\circ} \mathrm{C}$ in last hundred years (IPCC 2001). According to the Intergovernmental Panel on Climate Change, the temperature will be increasing continuously and in the next 50-100 years the temperature will increase by $5-6^{\circ} \mathrm{C}$ (IPCC 2000). This high elevation in earth temperature will cause serious changes in climate and other environmental conditions all over the world. Some of the signs of climate changes are currently found as in the increasing amounts of rainwater and number of tropical storms. It is strongly believed by researchers and scientists that one of the most important sources of greenhouse gas is MSW landfill gas. MSW landfill gas is primarily composed of methane and carbon dioxide. Methane is about 21 times stronger green house gas than carbon dioxide.

The use of landfills for MSW disposal is expected to increase in United States, Australia and many developing nations (Bogner, et al. 2000). About 55\% of all MSW generated in U.S.A is currently being disposed in approximately 2,300 municipal landfills (EPA 1998a). The U.S.A generated approximately 220 million tons of MSW in 1998 (EPA. 1998b). The estimated release of methane gas was approximately $9 \times 10^{5} \mathrm{mg} /$ year (Eklund, et al. 1998).

As the methane gas emission from landfills is causing serious harm to the environment of the world, currently more attention has been drawn in landfill gas recovery. It reduces greenhouse gas emissions and creates an alternative renewable source of energy through the systematic recovery and utilization of landfill gas (Alexander Klein, 2002). Methane gas provides a potential renewable power source (Pembina Institute, 2003). One cubic metre of waste has an energy value of 4 to 5 kilowatts $(\mathrm{kwh})$ or 0.5 litres of heating oil (Thompson and Tanapat, 2004; Tanapat and Thompson, 2003; Tanapat et al, 2003). In Canada, methane gas recovery from landfill gases is one of the most cost effective means to reduce greenhouse gas emissions. Currently forty-one landfills in Canada are capable to capture methane gas. This methane gas recovery results in an annual reduction of GHG (Greenhouse Gas) emissions of more than 7 megatonnes/year of carbon dioxide equivalents (Environment Canada, 2001). Approximately 70 percent of the captured gas in Canada is used for energy generation at 13 facilities and six of them generate electricity to sell to the grid (e.g., Keele St. Landfill in Toronto). Other seven facilities use the gas directly as an industrial process fuel (Environment Canada, 2001). 
Many researches have been performed on landfill gas generation and emission to help to estimate the amount of generation and emission of landfill gases. This estimates help to develop the landfill gas recovery systems. After studying the models on landfill gas generation and emission from landfills the developer of the RLFGM model has found that in North America the research is mostly focused on rate of deposition of solid waste into landfills. But European researchers consider individual waste category as well as the deposition rate of municipal solid waste into landfills. The developer of the RLFGM model believes this concept as more realistic approach to estimate the rate of generation and emission of methane gas from landfills. This persuaded the developer to focus research on the rate of deposition of MSW into landfills considering individual waste stream category. RLFGM model was developed for well-managed engineered landfills in North America.

This report focuses on developing a computer model to estimate the generation of methane gas and emission from landfills into the environment.

\subsection{Related works}

Landfill gas generation and emission into the environment is a very important issue today with respect to protect the environment of the current world. Many researches have been performed for the estimation of generation and emission of landfill gas in the past decades. For the purpose of development of the RLFGM model ten computer models have been studied. Studied models are from US EPA, IPCC, Environmental Protection Agency UK, the model developed from Department of Environment Food and Rural Affairs (DEFRA), UK and some other models. Among the studied models nine have been summarised in Appendix A (Tables 1 to 4).

\section{Main Body}

\subsection{RLFGM - Ryerson Landfill Gas Model}

RLFGM model is an excel spreadsheet model for a well-managed engineered landfill developed at Ryerson University, Toronto, Canada. The model provides a simple approach to estimate methane gas generation and emission from landfills. The model has been coded using the Microsoft Visual Basic and Excel. The RLFGM model has been developed for the simulation period of thirty years. 
RLFGM model has been designed using the help of IPCC tier two model (revised guidelines), the most recent national assessment model (Brown et. al. 1999) from UK and the model developed by LQM for the Department of Environment Food and Rural Affairs (DEFRA), UK. The national assessment model and LQM model are also based on IPCC tier two model with UK-specific modifications. But LQM added some more work on the determination of degradable organic carbon $(\mathrm{DOC})$ and fraction dissimilated $\left(\mathrm{DOC}_{\mathrm{F}}\right)$ and methane oxidation in addition to the national assessment model (Brown et. al. 1999). The model has been validated using the landfill gas emission model (LandGEM). RLFGM model estimates the maximum expected methane gas generation and emission potential based on factors such as the waste acceptance rates, methane generation rate constants $(\mathrm{k})$, and methane generation potential $(\mathrm{L} 0)$.

Relevant data regarding the different waste composition and different degradability rate for municipal solid waste was used during the development of the RLFGM model. The calculation of degradable organic carbon (DOC) and fraction dissimilated $\left(\mathrm{DOC}_{\mathrm{F}}\right)$ were considered from the LQM model developed from Department of Environment Food and Rural Affairs (DEFRA), UK. Methane generation potential $\left(\mathrm{L}_{0}\right)$ was calculated using the DOC.DOC $\mathrm{F}$ value. Three methane generation rate constants (rapidly degradable organic, moderately degradable organic and slowly degradable organic) were used in the design of RLFGM model considering the approach developed in the GasSim model. The model enables users to produce typical methane generation and emission rate from a well-managed engineered landfill located in North America.

\subsection{Limitations of the model}

- The RLFGM model was developed considering the landfills scenario in North America. It could be assumed that landfills in North America are well-managed as well as engineered landfills. It cannot be used for un-managed, non-engineered landfills.

- Lignin component was not considered in the simulation of the parameters $\mathrm{DOC}(\mathrm{x}) \cdot \mathrm{DOC} F)$.

\subsection{Waste category used in the simulation of RLFGM model}

The model was implemented by dividing the wastes into three degradability of waste category as slowly degradable, moderately degradable and rapidly degradable wastes. These three waste 
categories divided the waste streams into nine waste fractions as displayed in Appendix A, Table 5. The model characterizes the biodegradability of the rapidly, moderately and slowly degradable wastes by means of three main parameters as SDO (slowly degradable organic), MDO (moderately degradable organic) and RDO (rapidly degradable organic).

\subsection{RLFGM conceptual model}

RLFGM conceptual model has a modular structure, see Figure 1. The conceptual model is divided into four modules as below:

i) Methane Oxidation;

ii) Source;

iii) Methane Utilization and

iv) Methane emission into the environment;

The modules are described below:

i) Methane oxidation: RLFGM model was developed for a well-managed, engineered landfill in North America. According to IPCC (2000), the model used 0.1 as its oxidation factor (OX term in equation 2.4) for its implementation purpose.

ii) Source: The heart of the model is the source term. The source term simulates the generation of methane gas taking into account the following waste characteristics:

- The waste breakdown, the mix of different municipal solid waste fractions;

- The waste composition e.g. the proportion of rapidly degradable organic (paper, textiles, misc. combustible plus non-inert, composted putrescible), moderately degradable organic (ferrous and non ferrous metals), and slowly degradable organic (dense plastics, misc. combustible plus inert fines and glass). The waste composition is defined by the percentage of moisture content of the fraction, the proportion of cellulose and hemi-cellulose, as well as the percentage of the degradability of the cellulose and hemi-cellulose fraction, see Appendix A, Table 6.

- Physical parameters of waste;

- The biodegradability of the waste fractions (rapidly degradable organic, moderately degradable organic, slowly degradable organic), the rate of decay of waste fractions. The methanogenic degradation of carbon is simulated by dividing the different waste streams into three waste 
categories. These waste categories are divided into nine waste fractions (Appendix A, Table 5), as rapidly degradable organic (RDO - paper, textiles, misc. combustible (plus non inert), composted putrescible), moderately degradable organic (MDO - ferrous and non ferrous metals), and slowly degradable organic (SDO - dense plastics, misc. combustible (plus inert fines) and glass). The gas generation is then calculated using highly flexible multi-phases equations (Equations 2.1 to 2.3 ).

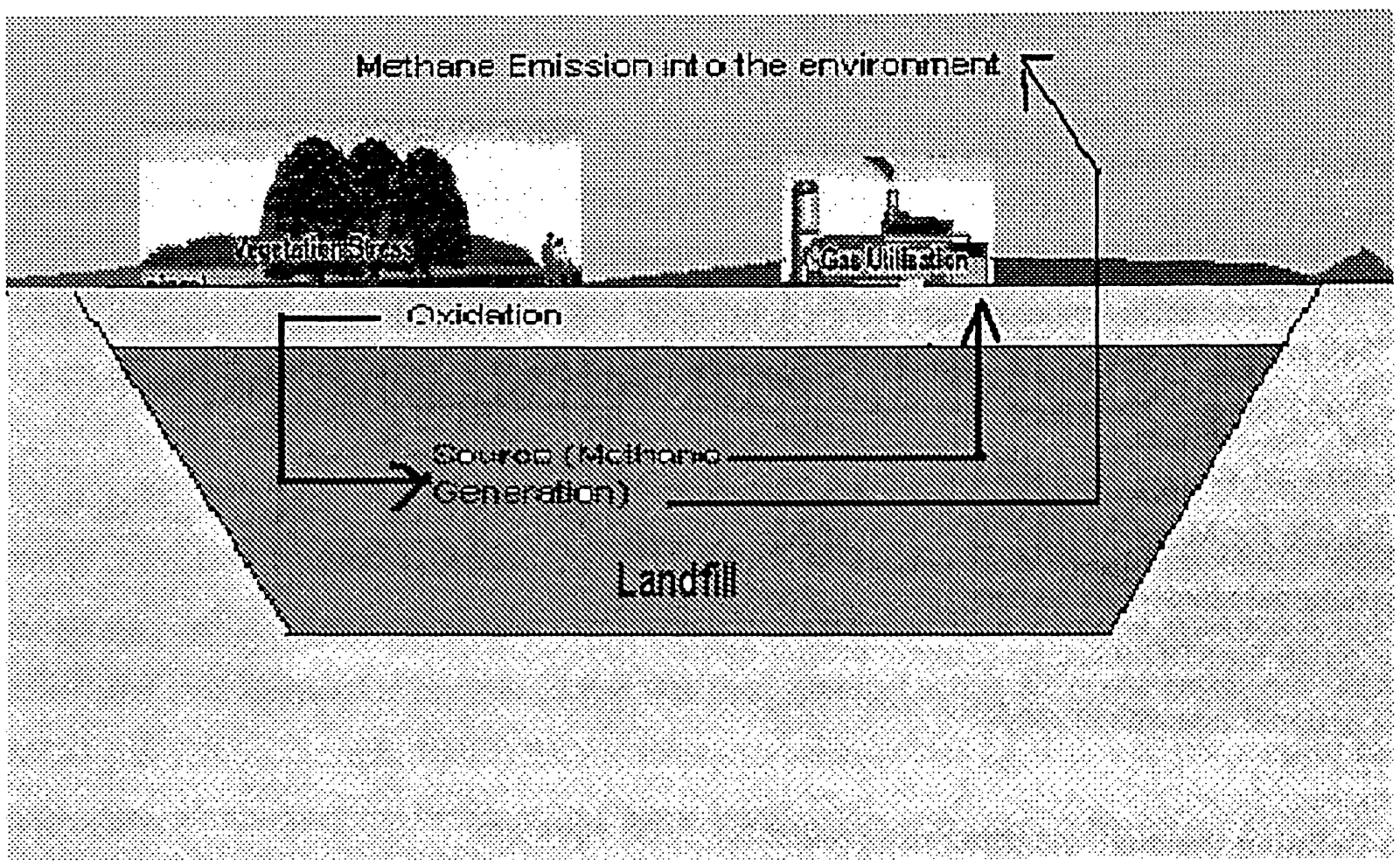

Figure 1 RLFGM conceptual model

Defining equations: RLFGM model used multilevel phases of equations for the generation of methane gas in landfills. The model used IPCC tier two model (revised guidelines), the latest national assessment model (Brown et. al. 1999) from UK and LQM model from the Department of Environment Food and Rural Affairs (DEFRA), UK.

The Revised IPCC (Guidelines for National Greenhouse Gas Inventions, 2000) tier two model is a first order decay (FOD) model. The model produces a time dependent emission profile that reflects the true pattern of the degradation process over time. The tier two methodology is described by the equations $2.1-2.2$ below. 


\section{a) Defining the rate of methane gas generation equation:}

- Methane gas generated in year $(\mathrm{Gg} / \mathrm{yr})=\sum_{\mathrm{x}}\left[\left(\mathrm{A} \cdot \mathrm{k}\left(\mathrm{MSW}_{\mathrm{T}}(\mathrm{x}) \cdot \mathrm{MSW}_{\mathrm{F}}(\mathrm{x}) \cdot \mathrm{L}_{0}(\mathrm{x})\right) \cdot \mathrm{e}^{-\mathrm{k}(\mathrm{t}-\mathrm{x})}\right]\right.$

for $x=$ initial year to year $t$

(Eq. 5.1 in IPCC 2000)

Where

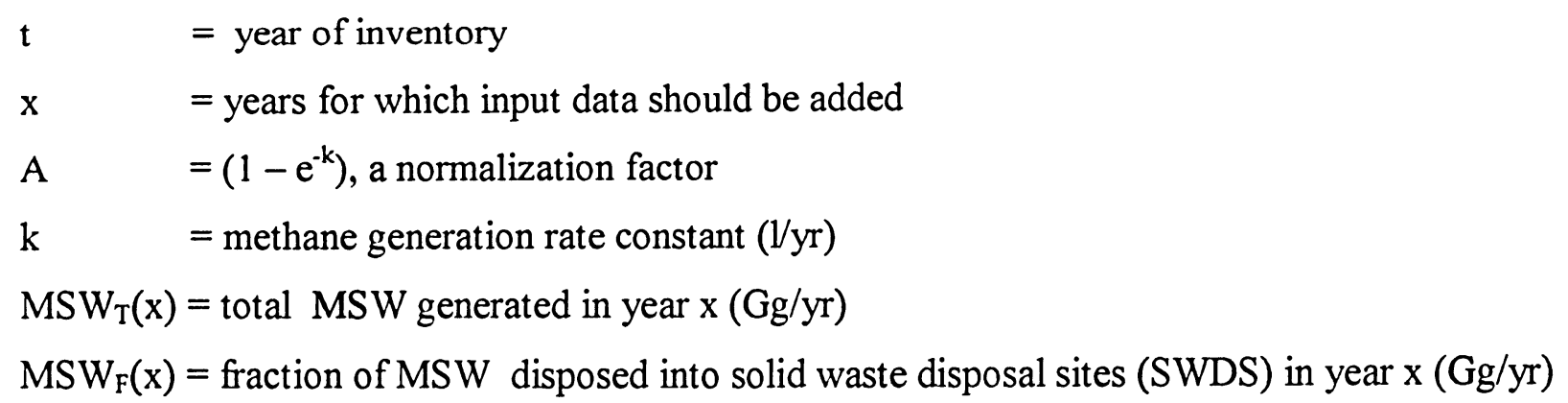

\section{Assumptions:}

$62 \%$ of generated solid waste is disposed into landfill

$\mathrm{k}=0.116$ for RDO (GasSim (Environmental Agency 2002a, UK)), and the current data set for the national assessment model

$k=0.076$ for MDO (GasSim (Environmental Agency 2002a, UK)), and the current data set for the national assessment model $k=0.046$ for SDO (GasSim (Environmental Agency 2002a, UK)), and the current data set for the national assessment model

b) Defining the methane generating potential, $L_{0}(x)$ equation:

- $\mathrm{L}_{0}(\mathrm{x})=\left[\mathrm{MCF}(\mathrm{x}) . \mathrm{DOC}(\mathrm{x}) \mathrm{DOC}_{\mathrm{F}}\right.$.F.16/12] $\left(\mathrm{Gg} \mathrm{CH}_{4} / \mathrm{Gg}\right.$ Waste) national assessment model, UK

Where

$\mathrm{MCF}(\mathrm{x})=$ methane correction factor in year, $\mathrm{x}$ (fraction)

$\operatorname{DOC}(\mathrm{x})=$ degradable organic carbon (DOC) in year, $\mathrm{x}$ (fraction) ( $\mathrm{Gg} \mathrm{C} / \mathrm{Gg}$ waste)

$\mathrm{DOC}_{\mathrm{F}}=$ fraction of $\mathrm{DOC}$ dissimilated

$\mathrm{F} \quad=$ fraction by volume of methane gas in LFG

$16 / 12=$ conversion from carbon to methane

\section{Assumptions:}

$\operatorname{MCF}(x)=1.0$ (considering managed solid waste disposal site) 
$\mathrm{F} \quad=0.5$

c) Defining degradable organic carbon (DOC) and fraction dissimilated $\left(\mathrm{DOC}_{\mathrm{F}}\right)$ : This is accepted from the LQM model from Department of Environment Food and Rural Affairs (DEFRA), UK.

\section{Defining Equation:}

- $\left(\mathrm{DOC}(\mathrm{x}) \cdot \mathrm{DOC}_{\mathrm{F}}\right)_{\mathrm{i}, \mathrm{j}}=\mathrm{M}(\mathrm{x})_{\mathrm{i}, \mathrm{j} .}\left({ }_{0} \mathrm{C}_{\mathrm{i}}+\% \mathrm{HC}_{\mathrm{i}}\right) . \% \mathrm{DC}_{\mathrm{i} \cdot}\left(1-\% \mathrm{MC}_{\mathrm{i}}\right) .72 / 162(\mathrm{Gg} \mathrm{C} / \mathrm{Gg}$ waste $)$

Where

$\mathrm{M}(\mathrm{x})_{\mathrm{i}, \mathrm{j}}=$ mass of waste category in year $\mathrm{x}$, degradability fraction $\mathrm{j}$ ( $\mathrm{Gg}$ waste)

$\% \mathrm{C}_{\mathrm{i}}=$ cellulose content of waste category $\mathrm{i}$ (fraction) $(\mathrm{Gg}$ cellulose $/ \mathrm{Gg}$ waste)

$\% \mathrm{HC}_{\mathrm{i}}=$ hemi-cellulose content of waste category $\mathrm{i}$ (fraction) ( $\mathrm{Gg}$ hemi-cellulose/ $\mathrm{Gg}$ waste)

$\% \mathrm{DC}_{\mathrm{i}}=$ degradability of the cellulose and hemi-cellulose of waste category $\mathrm{i}$ (fraction)

$\% \mathrm{MC}_{\mathrm{i}}=$ moisture content of waste category $\mathrm{i}$ (fraction)

$72 / 162=$ conversion from cellulose/hemi-cellulose to carbon $(\mathrm{Gg} \mathrm{C} / \mathrm{Gg}$ cellulose and hemicellulose)

Total degradable organic carbon that is dissimilated within each waste fraction (rapidly, moderately and slowly degradable organic) was calculated separately using the equation 2.3 . The calculated total degradable organic carbon was then summed across all waste categories ( $R D O$, $\mathrm{MDO}$ and $\mathrm{SDO})$. The term $\mathrm{DOC}(\mathrm{x}) \mathrm{DOC}_{\mathrm{F}}$ does vary with time as a function of the mass of each individual waste category but does not vary significantly with cellulose and hemi-cellulose contents, moisture contents of individual waste category. RLFGM model adopted this equation and the concept for its implementation. The $\mathrm{DOC}(\mathrm{x}) \mathrm{DOC}_{\mathrm{F}}$ value was used to derive the specific methane generating potential, $\mathrm{L}_{0}$ for each waste fraction. Total methane generating potential was calculated by the addition of the previous years $L_{0}$ value with the current year $L_{0}$ value. It was accepted accounting the concepts that the waste already disposed into the landfill yet generating the methane gas. This methane generating potential value provides the input into equation 2.1 mentioned, to obtain the value of the methane gas generated in each year.

iii) Methane utilization: According to the current US EPA regulations under the Clean Air Act, many larger landfills require to collect and combust landfill gas. The options available are flaring the gas or installing a landfill gas recovery and utilization system. There are a number of 
environmental and economic benefits of recovering landfill gas. Gas recovery systems reduce landfill gas odor and migration of landfill gas, reduce the danger of explosion and fire. The recovered methane gas is also a very good source for the generation of electricity in the current world. According to UK's national assessment, it was estimated that in the year of 2002 at least $63 \%$ of the total landfill gas generated in UK was flared or utilized and it increased to approximately $72 \%$ by 2005 . During the development of the RLFGM model it was assumed that $72 \%$ of methane gas would be recovered.

iv) Methane gas emission from landfills: Methane gas emission from landfills is normally controlled by engineering measures, e.g. the installation of engineered barriers (cap and liner) and gas collection systems. RLFGM model determined methane gas emissions from landfills based on comprehensive literature review. The RLFGM model assumes that methane gas generated and not collected would be emitted through the landfill cap or liner at a steady state and would be released into the surface to the atmosphere. RLFGM model assumes that $72 \%$ of methane gas recovery for its development purpose. RLFGM model reduces the emission of methane gas through the cap by biological methane gas oxidation. The model allows the use of the IPCC (2000) methodology which states that the oxidation factor for a well-managed landfill should be 0.1 based on available information. RLFGM model assumes oxidation factor as 0.1 for its design purpose. Assuming $72 \%$ recovery of methane gas and oxidation factor as 0.1 the model uses the IPCC (2000) tier two model for the calculation of methane gas emission into the environment. The equation is shown below:

\section{Defining Equation:}

- Methane emitted in year $\mathrm{t}(\mathrm{Gg} / \mathrm{yr})=\left[\mathrm{CH}_{4}\right.$ generated in year $\left.\mathrm{t}-\mathrm{R}(\mathrm{t})\right] .(1-\mathrm{OX})$

\section{(Eq. 5.2 in IPCC 2000)}

Where

$R(t)=$ recovered methane gas in inventory year $t(G g / y r)$

$\mathrm{OX}=$ oxidation factor

\section{Assumptions:}

Landfill gas recovered (flared or utilized) $=72 \%$ of the landfill gas generated

Oxidation Factor (methane oxidation) $=0.1$ 


\subsection{Model parameters}

i) Methane generation rate constants, $k$ : RLFGM model used three methane gas generation rate constants for $\mathrm{RDO}, \mathrm{MDO}$ and $\mathrm{SDO}$ components accounting the approach developed for the Environmental Agency's GasSim model, UK. For methane generation rate constant, k the IPCC (2000) proposed a single value of $\mathrm{k}$ as 0.05 per year corresponding to a half-life period of 15 years. Manely et al. (1990a; 1990b) first used three rate constants for slowly degradable, moderately degradable, and rapidly degradable wastes, and Brown et al. (1999) introduced three rate constants into the national assessment model, UK. The methane generation rate constants used by Manely et al. (1990a; 1990b), Brown et al. (1999) and GasSim models are given in Appendix A, Table 7. It was noted that in all cases, the half- life period of the slowly degradable organic is consistent with the IPCC (2000) value 0.05 . The half-life period for rapidly and moderately degradable wastes was increased. It has been found from comprehensive literature review that it has been accounted to avoid immediate peaks corresponding to short half-lives period in the simulation.

ii) Methane Correction Factor, MCF: Unmanaged solid waste disposal sites (SWDS) produce less methane gas compared to managed SWDS. It is because of a larger fraction of waste decomposes aerobically in the top layers of unmanaged SWDS. According to IPCC (2000), (Appendix A, Table 8) the methane correction factor for a managed SWDS should be 1.0. Values less than 1.0 may be adopted for developing or countries with unmanaged solid waste disposal sites. It is assumed that in North America all landfills are well-managed and engineered landfills. For that reason RLFGM model used 1.0 as its methane correction factor value during its development.

iii) Methane Oxidation, OX: According to IPCC (2000) the oxidation factor for well-managed landfills at a national level should be 0.1 . Considering that approach the model assumed 0.10 as its methane oxidation factor value for its implementation.

iv) Methane Content in LFG, F (percentage by volume): Typical landfill gas composition is shown in Appendix A, Table 9. The landfill gas composition is influenced by the decomposition of landfill solid waste. The decomposition of biodegradable waste in landfills gives rise to both methane gas and carbon dioxide in approximately equal quantity by volume. The mechanics of this process are governed by a number of different biochemically mediated reactions (AFRC, 
1988). It could be said that the actual quantity of methane gas or carbon dioxide produced by decomposition will vary according to the dominant microbiological processes. In older uncapped sites, natural diffusion of air through the cover materials led to a greater degree of aerobic degradation, and thus the proportion of methane gas produced changed from 50:50. This reflected the increased carbon dioxide and reduced methane gas production. For an older unengineered not well-managed landfill the percentage of methane gas content in LFG may be of $30 \%$. The RLFGM model used a methane gas content of $50 \%$ in LFG for its investigation purpose. For the purpose of developing the RLFGM model, a value of 0.5 for methane gas content in LFG has been accepted.

v) Degradable organic carbon (DOC) and fraction dissimilated $\left(\mathrm{DOC}_{\mathrm{F}}\right)$ : The IPCC states that the fraction of the degradable organic carbon that actually degrades to release methane gas and carbon dioxide should be by default 0.77 (if lignin is excluded from the DOC) or between 0.5-0.6 (if lignin is included). But the LQM model from Department of Environment Food and Rural Affairs (DEFRA), UK used the equation 2.3 for the calculation of total degradable organic carbon that is dissimilated within each waste fraction (rapidly, moderately and slowly degradable organic). The model calculated it separately and used for its implementation. The RLFGM model used this approach for its study purpose. The methanogenic degradation of carbon was implemented by dividing the different waste streams into three waste categories (Appendix A, Table 5), as RDO - (paper, textiles, misc. combustible plus non inert, composted putrescible), MDO - (ferrous and non ferrous metals), and SDO - (dense plastics, misc. combustible plus inert fines and glass).

The term $\mathrm{DOC}(\mathrm{x}) \cdot \mathrm{DOC}_{\mathrm{F}}$ was calculated based on moisture content, cellulose, hemi-cellulose and degradability fraction of cellulose and hemi- cellulose of individual waste category. Typical MSW contains cellulose, hemi-cellulose and lignin (Barlaz et al., 1990) components. Cellulose and hemi-cellulose account for 91 percent of the methane gas potential in MSW (Barlaz et al. 1989). The model does not consider lignin component for its study purpose. Some researchers (Eleazer et al., 1997) found that the lignin degrades slowly under anaerobic conditions. Some other researchers have demonstrated that lignin has no methane gas generating potential because it is recalcitrant under the anaerobic conditions (Young and Frazer 1987). Based on these studies it was decided not to consider the lignin component for the investigation of the RLFGM model. 


\section{Results and Discussions}

This section discusses the output provided by the model. Three steps have been adopted for the generation and emission of methane gas in RLFGM model.

i) $\operatorname{DOC}(x) \cdot \mathrm{DOC}_{\mathrm{F}}: \mathrm{DOC}(\mathrm{x}) \cdot \mathrm{DOC}_{\mathrm{F}}$ value has been calculated using the equation 2.3 in the implementation of RLFGM model. It has been calculated for different waste streams category (Appendix A, Table 5). A sample model output is shown in Appendix A, Table 10, which is based on data input in Appendix A, Table 6.

$\mathrm{DOC}(\mathrm{x}) \cdot \mathrm{DOC}_{\mathrm{F}}$ does vary with time with respect to mass of solid waste disposed into landfills. It does not vary significantly with moisture content, cellulose, hemi-cellulose and degradability fraction of cellulose and hemi-cellulose of individual waste category. This was assumed in the design of the RLFGM model.

ii) Methane generating potential, $L_{0}$ : The methane gas generating potential $L_{0}$ has been calculated using the equation 2.2. It used $\mathrm{DOC}(\mathrm{x}) \cdot \mathrm{DOC}_{\mathrm{F}}$ values as input values. Calculated values were summed up for each degradability rate (RDO, MDO, SDO). During the implementation of RLFGM model it has been assumed that the solid waste already disposed into landfill yet producing the methane gas. So it added the $\mathrm{L}_{0}$ of the current year to the previous years. The Table 11 in Appendix A shows the sample output of $\mathrm{L}_{0}$ of the model simulation.

iii) Methane gas generation and emission rates from landfills: The above equation 2.1 and equation 2.4 have been used for the generation and emission of methane gas from landfills. One set of municipal solid waste data (Appendix A. Table 6) has been used for the simulation of methane gas generation and emission from landfills. It has been assumed from current practice that $62 \%$ of the generated solid waste would be disposed into landfills and $72 \%$ of the landfill gas generated would be recovered (flared or utilized). The rate of methane gas generation and emission from landfill has been displayed in graphs (see Figure 2 and Figure 3). During the 30 years (from 1995 to 2025) simulation period from year 1998 to year 2007 methane gas generation rate was high. Methane gas emission rate was high from year 1998 to year 2011. Rate of methane gas generation and emission from landfill both have decreased with time after that period. The highest methane gas generation rate and emission rate were found in the year of 2000. 


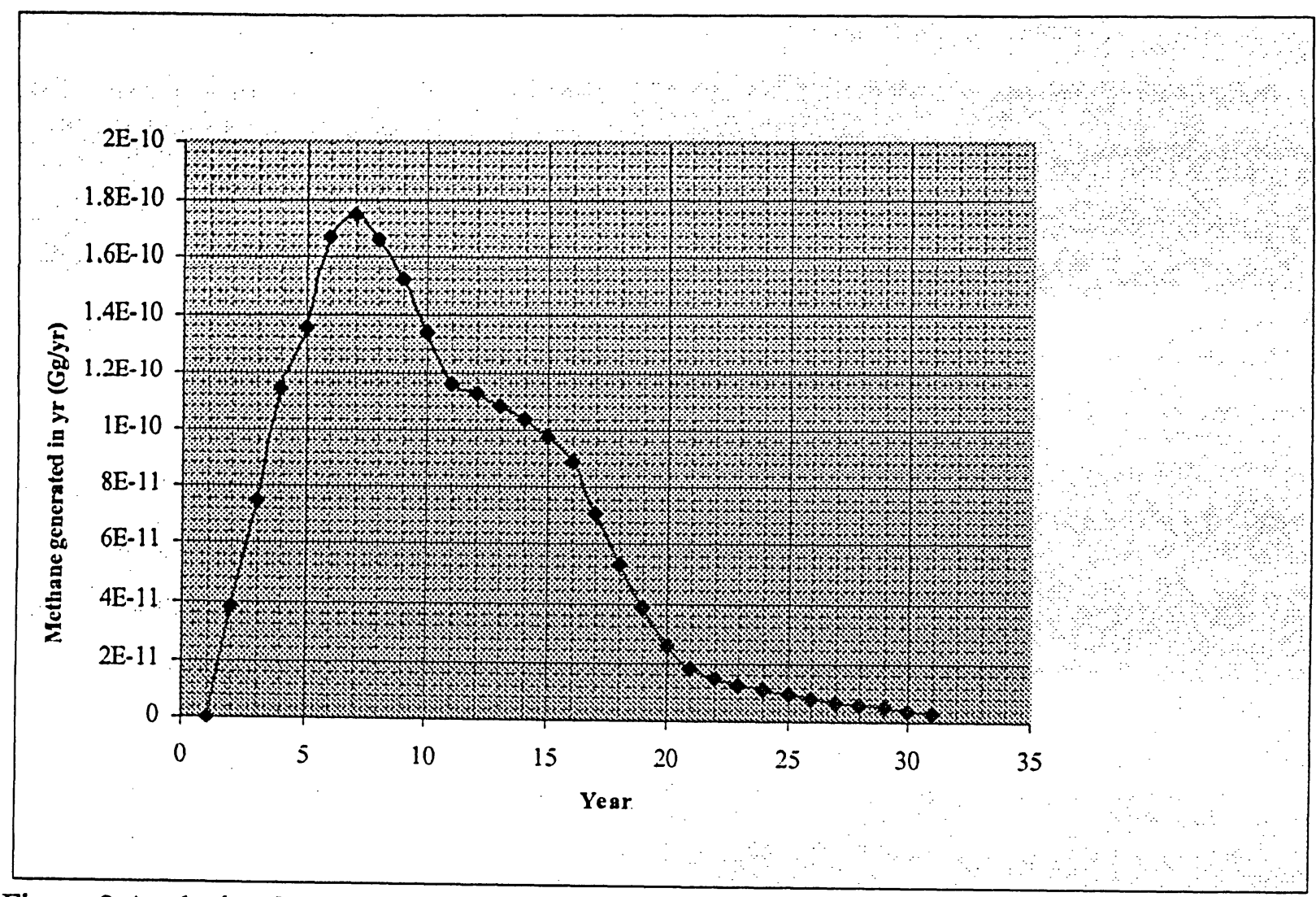

Figure 2 Analysis of methane gas generation rate $(\mathrm{Gg} / \mathrm{yr})$ from landfill 


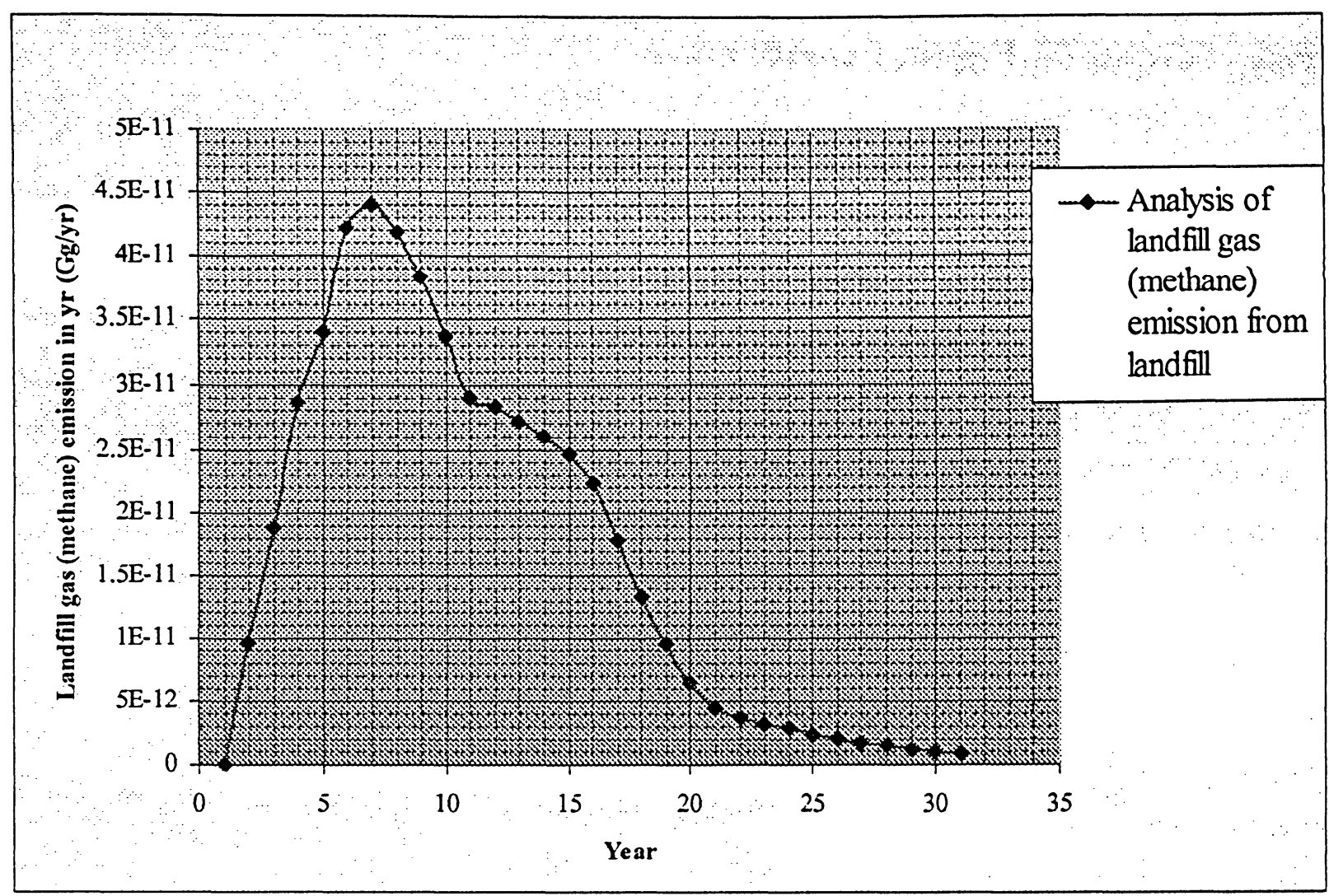

Figure 3 Analysis of methane gas emission rate $(\mathrm{Gg} / \mathrm{yr})$ from landfill

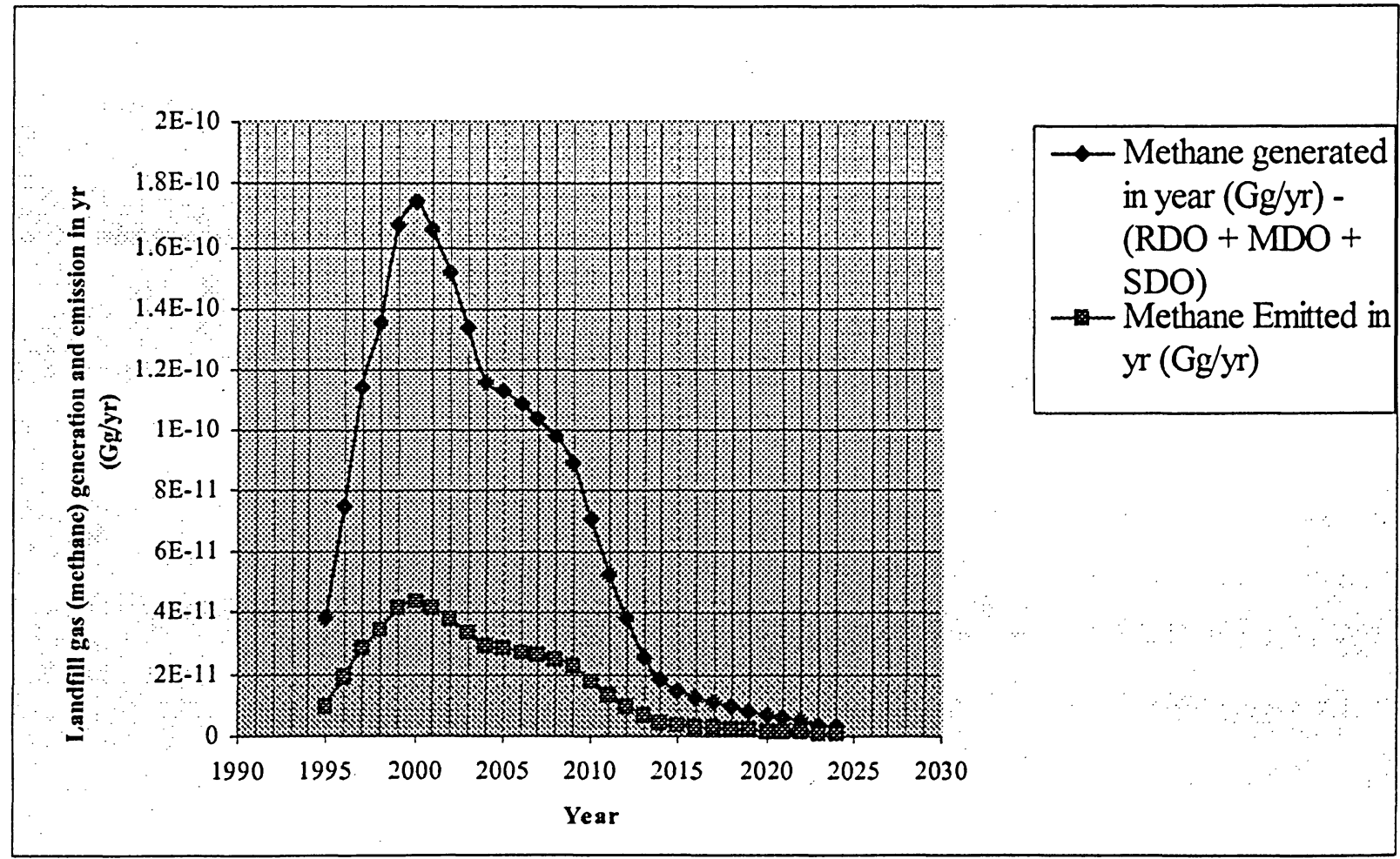

Figure 4 Comparing methane gas generation and emission rate $(\mathrm{Gg} / \mathrm{yr})$ from landfill 


\section{Data inputs and model verification}

The model verification has been performed by comparing the output of the RLFGM model with the LandGEM model from US EPA. The LandGEM model uses the first order decay (FOD) equation (Appendix A, Table 1) where as RLFGM model uses multi-phases equations for the generation and emission of methane gas from landfills. The LandGEM model has been simulated using the same set of solid waste mass input data from Appendix A, Table 6. While simulating the LandGEM model only RDO component of the waste from Appendix A, Table 6 has been accepted. It excluded the MDO and SDO components as moderately degradable organic and slowly degradable organic may not produce methane gas.

The major difference between the models is the calculation steps of the methane gas generating potential $\left(\mathrm{L}_{0}\right)$. The LandGEM model uses the constant values as CAA conventional $170 \mathrm{~m}^{3} / \mathrm{Mg}$, CAA arid area $170 \mathrm{~m}^{3} / \mathrm{Mg}$, inventory conventional $100 \mathrm{~m}^{3} / \mathrm{Mg}$, inventory arid area $100 \mathrm{~m}^{3} / \mathrm{Mg}$, inventory wet $96 \mathrm{~m}^{3} / \mathrm{Mg}$. For the verification purpose $100 \mathrm{~m}^{3} / \mathrm{Mg}$ has been used for LandGEM model simulation accounting inventory conventional approach.

The RLFGM model considers different components (RDO, MDO and SDO components) of waste streams (Appendix A, Table 6) and calculated the $\mathrm{DOC}(\mathrm{x}) \cdot \mathrm{DOC} \mathrm{C}_{\mathrm{F}}$ value separately. The summation of $\mathrm{DOC}(\mathrm{x}) \cdot \mathrm{DOC}_{\mathrm{F}}$ value of all components was used for the implementation of $\mathrm{L}_{0}$ value. The calculation of methane gas generation has been accomplished by the addition of $\mathrm{L}_{0}$ value of the current year with the previous years. This value is lower than the $L_{0}\left(100 \mathrm{~m}^{3} / \mathrm{Mg}\right)$ value from the LandGEM model making the model output lower. The output graph for the methane gas emission of both of the models resembles similar, see Figure 4 and Figure 5 . The model output for methane gas emission from landfills for both of the models are compared in Appendix A, Table 13. It has been found that for the RLFGM model maximum methane gas emission from landfills has occurred in the year the of 2000 and for LandGEM it has occurred in the year of 2011. The parameters used for the simulation of LandGEM model are shown in Appendix A, Table 12. A comparing table (Appendix A, Table 14) has been shown to focus the differences between RLFGM model and LandGEM model simulation parameters and results. 


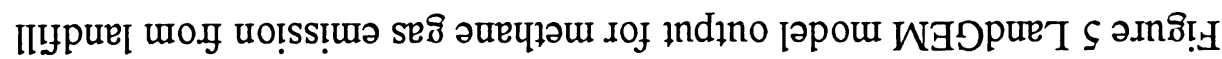

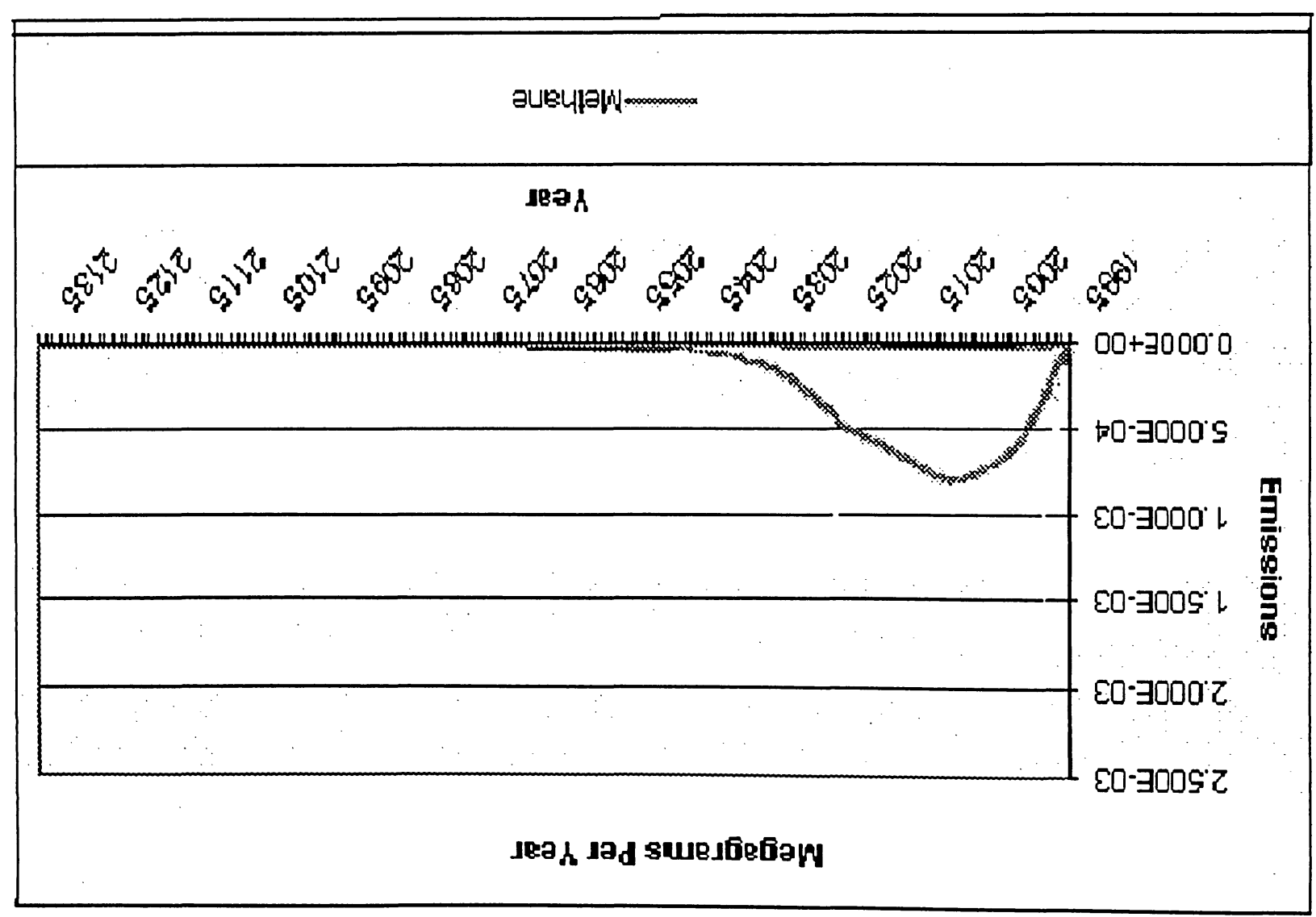




\section{Conclusion}

RLFGM model has been developed for the purpose of the generation and emission of methane gas from landfills. The model has been constructed using the help of IPCC tier two model (revised guidelines), the most recent national assessment model (Brown et. al. 1999) from UK and the LQM model developed from the Department of Environment Food and Rural Affairs (DEFRA), UK. The model was validated using the help of LandGEM model. The implementation was performed with some model-defined data sets as well as some user-defined data sets. The data sets used are methane gas generation rate constants, $\mathrm{k}$ for rapidly degradable organic, moderately degradable organic and slowly degradable organic, methane correction factor and methane oxidation. The user-defined data sets are yearly rate of solid waste disposal into landfills. Degradable organic carbon $(\mathrm{DOC})$ and fraction dissimilated $\left(\mathrm{DOC}_{\mathrm{F}}\right)$ were calculated using the model input data and used for the calculation of methane generating potential $\left(\mathrm{L}_{0}\right)$. During the validation of the RLFGM model using the help of the LandGEM model it was found that the output graph for the methane gas emission from landfill resembled similar with the LandGEM model output but the value was smaller. The RLFGM model calculates the methane gas generation and emission rate considering three types of waste degradability fraction as rapidly degradable organic, moderately degradable organic and slowly degradable organic. The waste fractions are described by the moisture content, cellulose content, hemi-cellulose content of the waste fraction, degradability of the cellulose and hemi-cellulose of waste category. It was found that it gives the realistic output with respect to individual landfill site, taking into account of specific waste streams and deposition rates. It has been concluded as one of the greatest benefits of the RLFGM model. 


\section{References}

- AFRC (1988). A basic study of landfill microbiology and biochemistry. Department of Energy Renewable Energy Research \& Development Programme, Energy Technology Support Unit Report ETSU B 1159, ETSU, Culham.

- Alexander, Klein (2002). "Gasification: An Alternative Process for Energy Recovery and Disposal of Municipal Solid Wastes". ”. Department of Earth and Environmental Engineering Fu Foundation, School of Engineering and Applied Science, Columbia University.

- Barlaz M.A., Ham R.K. and Schaefer D.M. (1990). "Methane production from municipal refuse: A review of enhancement techniques and microbial dynamics." Critical Reviews in Env. Control. 19(6): 557-584.

- Bingemer, H.G. and P. J. Crutzen (1987). "The production of methane from solid wastes." Journal of Geophysical Research, 92 (D2), pp. 2181 - 2187.

- Bogner, J.E., Matthews, E., Katzenstein, A., Blake, D. and Carolan, M. 2000. Green house gases emissions from landfills: What we know and what we don't know. ISWA World Congress. Paris. France.

- Brown, et al. (1999). Methane emissions from UK landfills. Final report for The Department of the Environment, Transport and the Regions. Report AEAT-5217. AEA

- Cornell Composting Science and Engineering (April 9, 1996). "The effect of lignin on biodegradability". http://compost.css.cornell.edu/calc/lignin.html

- D. Almorza, C. A. Brebbia, D. Sale and V. Popov, Waste Management and the Environment, pp 481-487.

- Eklund, Bart, Anderson, Eric P., Walker, Barry L., and Burrows, D.B. 1998.

- Eleazer W.E., Odle W.S. III, Wang Y and Barlaz M.A. (1997). "Biodegadability of municipal waste components in laboratory-scale landfills." Env. Sci. Tech. 31: 911-917.

- Environmental Science \& Technology. "Characterization of Landfill Gas Composition at the Fresh Kills Municipal Solid Waste Landfill." 32 (15), pp 2233 - 2237. Austin, TX.

- Environment Canada (August, 2006). "Information on greenhouse gas sources and sinks" (http://ncrweb.ncr.ec.gc.ca/pdb/ghg/inventory_report/1990_02_report/c8_e.cfin) 
- Environment Agency, UK (November 2002). "Guidance on the management of landfill gas". (http://www.sepa.org.uk/pdf/consultation/closed/2003/landfill/guidance_landfill_gas.pdf)

- Environment Agency and ETSU (1999). "HELGA: Health and Environmental Risk Effects from Landfill Gas." (http://www.lqm.co.uk/downloads/project_profiles/w01-helga.pdf).

- EPA, USA (1998b) Waste management practices. (www.epa.goviepaoswerinonhw/muncpl/factbook/internet/mswf/disp.htm.

- Gary M Attenborough (Golder Associates (UK) Ltd.), David H Hall (Golder Associates (UK) Ltd.), Robert G Gregory (Land Quality Management Ltd.), Louise McGoochan (Environment Agency), 2002. Development of a landfill gas risk assessment model: GasSim.

- Golder Associates, UK (November 2005). "UK landfill methane emissions: Evaluation and appraisal of waste policies and projection to 2050".

(http://www defra.gov.uk'science'project data'DocumentLibrary'GA01083/GA01083 3432 FR P.pdf).

- Good Practice Guidance and Uncertainty Management in National Greenhouse Gas Inventories (IPCC 2000a). (http://www.ipcc-nggip.iges.or.jp/public/gp/english/5 waste.pdf).

- H. Lanier Hickman, Jr., Principles of Integrated Solid Waste Management, pp 420 - 438.

- Heijo Scharff, NV Afvalzorg (October 2005). "Landfill gas production and emission on former landfills." North East South West Interreg IIIC. (http://www'sufalnet.netiget.php?f.588).

- HotRot composting system limited, England. "Composting of food and putrescible wastes" (http://wuw hotrotsystems.com/content/library/Food wastes HCS.pdf)

- Intergovernmental Panel on Climate Change (IPCC) (1997). Revised 1996 IPCC Guidelines for National Greenhouse Gas Inventories: Volume 3 reference manual. J.T. Houghton et al., IPCC/OECD/IEA, Paris, France.

- IPCC (1996). "Climate Change 1995: The Science of Climate Change", Contribution of working group 1 to the second assessment report of the Intergovernmental Panel on Climate Change, Cambridge University Press.

- John Pichtel, Waste Management Practices - Municipal, Hazardous and Industrial, pp 321 324.

- John Walkenbach, Excel 2002 Formulas. 
- Land Quality Management Ltd. for the department of environment food and rural affairs, UK. (January 2003). Report on "Methane emissions from landfill sites in the UK". (http://www.airquality.co.ukiarchiveireportsicat07/LQM_methane_emissions.pdf).

- Leslie Heasman (May 2005). "Waste acceptance criteria: a waste management perspective" (http://www.esauk.org/events/previous/050525Leslie Heasman.pdf)

- Manley BJW, Gregory RG and Gardner N (1990a). An Assessment of the UK Landfill Gas Resource, pp 193-203. In: Richards GE and Alston YR (Eds) Landfill Gas: Energy and Environment 90, Third International Landfill Gas Conference, Bournemouth.

- Manley BJW, Wilson DC and Tillotson HS (1990b). National Assessment of Landfill Gas Production. Department of Energy ETSU Report B1192, Energy Technology Support Unit, Culham.

- Oonk, H. and T. Boom (1995). "Landfill gas formation, recovery and emissions", TNO-report R95-203, TNO, Apeldoorn, Netherlands.

- Pembina Institute (2003). "Green power programs in Canada - 2003".

- Ryan J. Kelly, Blacksburg, Virginia (May 2, 2002). "Solid waste biodegradation enhancements and the evaluation of analytical methods used to predict waste stability". Thesis submitted to the Faculty of Virginia Polytechnic Institute and State - University in partial fulfillment for the degree of Master of Science in Environmental Science and Engineering. (http://scholar.lib.vt.edu/theses/available/etd-06042002-100518/unrestricted/etd.pdf)

- Sams, Excel 2000 Programming.

- S. Thompson* and S. Tanapat, 2004. Modeling Methane Generation for Different Waste Management Options. Environmental Informatics Archives, Volume 2, pp 242 - 251.

- Stege G. Alex, Murray Dana L. (November 2003). Prepared on behalf of Landfill Methane Outreach Program U.S. Environmental Protection Agency and U.S. Agency for International Development. "Mexico landfill gas model" (http:/www.epa.gov/lmopint/UsersManualMexico LFG modelV1 5.pdf

- "Types of solid wastes". (http://edugreen.teri.res.in/explore/solwaste/types.htm).

- United States Environmental Protection Agency (EPA), Office of research and development, National Risk Management Research Laboratory (NRMRL), and Clean Air Technology Centre 
(CATC), Research Triangle Park, North Carolina (May 2005). "Landfill gas emission model (LandGEM)".

- V. Popov, H. Itoh, C.A. Brebbia and S. Kungolos, Waste Management and the Environment II, pp $419-427$.

- Young L.Y and Frazer A.C. (1987). "The fate of lignin and lignin derived compounds in anaerobic environments." Geomicrobiology J. 5: 261. 


\section{Appendix A:}

Table 1 Summery of the landfill gas generation and emission models from United States

Environmental Protection Agency (US EPA)

\begin{tabular}{|c|c|}
\hline \begin{tabular}{|l|} 
Model Name \\
\end{tabular} & Landfill gas emissions model \\
\hline Team & US EPA (1998) \\
\hline & $\begin{array}{l}Q_{T}=\sum_{i=1}^{n} 2 k L_{o} M_{i} e^{-k t_{i}} \\
\mathrm{Q}_{\mathrm{T}}=\text { total gas emission rate from a landfill, mass/time } \\
\mathrm{k}=\text { landfill gas emission constant time } \mathrm{e}^{-1} \\
\mathrm{~L}_{0}=\text { methane generation potential, volume/mass of waste } \\
\mathrm{t}_{\mathrm{i}}=\text { age of the } \mathrm{i}^{\text {th }} \text { section of waste, time } \\
\mathrm{M}_{\mathrm{i}}=\text { mass of wet waste, placed at time } \mathrm{i} \\
\mathrm{N}=\text { total time period of waste placement }\end{array}$ \\
\hline $\begin{array}{l}\text { Components } \\
\text { incorporated } \\
\text { with the } \\
\text { model }\end{array}$ & $\begin{array}{l}\text { This model is based on a first-order decomposition model. There is a choice } \\
\text { in the model between "Codisposal" and "No Codisposal". } \\
\text { Assumptions: } \\
\text { 1. The model assumes that } \mathrm{CO}_{2} \text { gas emission rates are the same as the } \\
\text { methane gas emission rates. } \\
\text { 2. Landfill gas emission rates are twice the methane gas emission rates. } \\
\text { 3. The generation of methane gas from a landfill is a function of two values: } \\
\mathrm{k} \text {, the methane gas generation rate and } \mathrm{L}_{0} \text {, the methane gas generation } \\
\text { potential and they are considered constants values. } \\
\text { 4. Two different set of model default values used for the calculation of } \\
\text { emissions: a set of default values for determining applicability of the NSPS or } \\
\text { emission guidelines (the CAA defaults) for MSW landfills and a set of } \\
\text { default values based on emission factors from AP-42 (the AP-42 defaults). } \\
\text { Limitation: } \\
\text { 1. A more sophisticated calculation method was not justified because of the } \\
\text { limitation of the data availability for landfills, such as data on the quantity, } \\
\text { age, and deposition refuse in the landfills. }\end{array}$ \\
\hline
\end{tabular}




\begin{tabular}{|c|c|}
\hline Model Name & Firșt Order Decay model (FOD) \\
\hline Team & US Environmental Protection Agency (EPA) \\
\hline $\begin{array}{l}\text { Equation } \\
\text { used }\end{array}$ & $\begin{array}{l}\text { 1. Total amount of landfill gas generated in current year, } \\
\begin{array}{l}\text { - } \mathrm{Q}_{\mathrm{T}}=2 \mathrm{~L}_{0} \mathrm{R}\left(\mathrm{e}^{-\mathrm{kc}}-\mathrm{e}^{-\mathrm{kt}}\right) \\
\mathrm{Q}_{\mathrm{T}}=\sum_{\mathrm{i}=1}^{\mathrm{n}} 2 \mathrm{~kL}_{0} \mathrm{M}_{\mathrm{i}} \mathrm{e}^{-\mathrm{kti}}\end{array}\end{array}$ \\
\hline $\begin{array}{l}\text { Components } \\
\text { incorporated } \\
\text { with the } \\
\text { model }\end{array}$ & $\begin{array}{l}\text { Assumptions: } \\
\text { 1. Requires as input solid waste disposal data including (for past } 20-25 \text { or } \\
\text { more years). Data inputs are: } \\
\text { - Composition of the waste and } \\
\text { - Conditions at the SWDS. } \\
\text { 2. The parameters used are - } \\
\mathrm{k}=\text { Methane generation rate constant } \\
\mathrm{L}_{0}=\text { Total methane generation potential of the waste } \\
\quad=(\mathrm{MCF} \bullet \mathrm{DOC} \bullet \mathrm{DOC} \cdot \mathrm{F} \bullet 16 / 12) \\
\text { 3. The rate of degradation for waste disposed at SWDS needs to be } \\
\text { determined. } \\
\text { 4. FOD method takes the timing of the emissions into consideration and gives } \\
\text { a more realistic picture of the actual emissions during the inventory year in } \\
\text { question. } \\
\text { Limitations: } \\
\text { 1. Default values needed in the FOD method are insufficient. } \\
\text { 3. The FOD method considers the time factor of the degradation process and } \\
\text { produces annual emission estimates that reflect this process. This process can } \\
\text { take years, even decades. }\end{array}$ \\
\hline
\end{tabular}

Table 2 Summery of the landfill gas generation and emission models from the Intergovernmental Panel on Climate Change (IPCC)

\begin{tabular}{|l|l|}
\hline Model Name & IPCC Default model IPCC guidelines, 1996) \\
\hline Team & The Intergovernmental Panel on Climate Change (IPCC, 1996) \\
\hline
\end{tabular}




\begin{tabular}{|c|c|}
\hline & $\begin{array}{l}\text { 1. Methane gas emissions }(\mathrm{Gg} / \mathrm{yr})=\left(\mathrm{MSW}_{\mathrm{T}} \mathrm{MSW}_{\mathrm{F}} \cdot \mathrm{MCF} \cdot \mathrm{DOC} \cdot \mathrm{DOC}_{\mathrm{F}} \cdot\right. \\
\mathrm{F} \cdot 16 / 12-\mathrm{R}) \cdot(1-\mathrm{OX}) \\
\text { 2. } \mathrm{DOC}(\text { Degradable organic Carbon })=0.4 \bullet(\mathrm{A})+0.17 \bullet(\mathrm{B})+0.15 \bullet(\mathrm{C})+ \\
0.30 \bullet(\mathrm{D}) \\
\text { 3. } \mathrm{DOC}_{\mathrm{F}}(\text { Fraction DOC dissimilated })=0.014 \bullet \mathrm{T}+0.28 \\
\text { 4. } \mathrm{F}=\text { fraction of methane in landfill gas, } 50 \%(\mathrm{IPCC} \text { default value }) \\
\text { 5. } \mathrm{OX}=\text { oxidation factor, } 0(\mathrm{IPCC} \text { default value }) \\
\left.\text { 6. Methane Correction Factor }=[1 / 1+\mathrm{R})^{\mathrm{T}}\right] \bullet\{1-1 /[\mathrm{T} \bullet \ln (1+\mathrm{R})]\} \\
\text { 7. } \mathrm{MSW}_{\mathrm{F}}(\text { Fraction of MSW disposed into solid waste disposal sites })= \\
\left(\mathrm{MSW}_{\mathrm{T}} \bullet \mathrm{CC}\right) \cdot \mathrm{SW}_{\mathrm{TREAT}} \cdot \mathrm{MSW} \mathrm{REC}_{\mathrm{REC}}\end{array}$ \\
\hline $\begin{array}{l}\text { Components } \\
\text { incorporated } \\
\text { with the } \\
\text { model }\end{array}$ & $\begin{array}{l}\text { IPCC default method is a simple, transparent and easy to use. IPCC default } \\
\text { method can produce relatively good estimates of the potential future } \\
\text { emissions. } \\
\text { Assumptions: } \\
\text { 1. The model requires only input of a limited set of parameters. The input } \\
\text { parameters are: } \\
\text { - The composition of the waste and } \\
\text { - The conditions of the SWDS. } \\
\text { 2. The model does not need to determine the rate of decomposition of waste } \\
\text { at SWDS. The IPCC guidelines contain the default values for the most of the } \\
\text { data needed in the model. } \\
\text { Limitations: } \\
\text { 1. IPCC default methodology provides estimates on potential methane gas } \\
\text { emissions without incorporating any time factors. } \\
\text { 2. The method will produce fairly good estimates of the yearly emissions if } \\
\text { the yearly amounts as well as composition of waste disposed have been nearly } \\
\text { constant for long periods. Increasing amounts of waste disposed will lead to } \\
\text { an overestimation, and decreasing amounts correspondingly to } \\
\text { underestimation of yearly emissions. } \\
\text { 3. The uncertainties in the emission estimates produced by IPCC method are }\end{array}$ \\
\hline
\end{tabular}




\begin{tabular}{|c|c|}
\hline & $\begin{array}{l}\text { large in most countries. } \\
\text { 4. Need improved reporting schemes regarding LFG recovery plants. }\end{array}$ \\
\hline Model name & IPCC tier two model (2000) \\
\hline Team & IPCC (The Intergovernmental Panel on Climate Change) revised guidelines \\
\hline $\begin{array}{l}\text { Equations } \\
\text { used }\end{array}$ & $\begin{array}{l}\text { 1. Methane gas generated in year } t(\mathrm{Gg} / \mathrm{yr})=\Sigma_{\mathrm{x}}\left[\left(\mathrm{A} \cdot \mathrm{k} \cdot \mathrm{MSW}_{\mathrm{T}}(\mathrm{x}) \cdot \mathrm{MSW} \mathrm{F}(\mathrm{x}) \text {. }\right.\right. \\
\left.\left.\mathrm{L}_{0}(\mathrm{x})\right) \cdot \mathrm{e}^{-\mathrm{k}(\mathrm{t}-\mathrm{x})}\right] \\
\text { 2. Methane gas generating potential, } \mathrm{L}_{0}(\mathrm{x})=\left[\mathrm{MCF}_{(\mathrm{x})} \cdot \mathrm{DOC}_{(\mathrm{x}) \cdot .} \mathrm{DOC}_{(\mathrm{F}) \cdot} \mathrm{F} \text {. }\right. \\
16 / 12](\mathrm{Gg} \mathrm{CH} / \mathrm{Gg} \text { waste }) \\
\text { 3. Methane gas emitted in year } \mathrm{t}(\mathrm{Gg} / \mathrm{yr})=\left[\mathrm{CH}_{4} \text { generated in year } \mathrm{t}-\mathrm{R}(\mathrm{t})\right] \text {. } \\
(1-\mathrm{OX})\end{array}$ \\
\hline $\begin{array}{l}\text { Components } \\
\text { incorporated } \\
\text { with the } \\
\text { model }\end{array}$ & $\begin{array}{l}\text { Assumptions: } \\
\text { 1. IPCC tier two model is a first order decay (FOD) model. The model } \\
\text { considers time to determine emission profile that reflects the true pattern of } \\
\text { the degradation process over time. } \\
\text { 2. Tier two model does site specific NMOC concentration measurements. }\end{array}$ \\
\hline
\end{tabular}

Table 3 Summery of the landfill gas generation and emission models from Environment Agency, UK and the model developed from the Department of Environment Food and Rural Affairs (DEFRA), UK.

\begin{tabular}{|c|c|}
\hline Mod & $\begin{array}{l}\text { GasSim (Landfill Gas Risk Assessment Tool), developed for Environment } \\
\text { Agency (England), 2002a }\end{array}$ \\
\hline Team & Golde \\
\hline used & 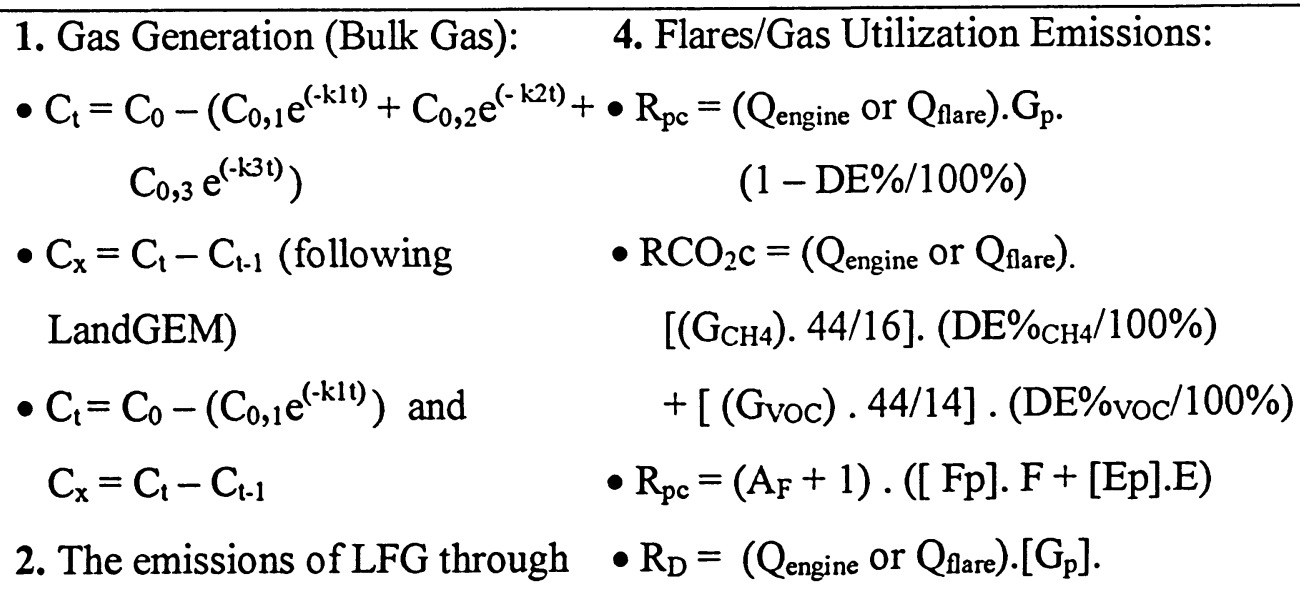 \\
\hline
\end{tabular}




\begin{tabular}{|c|c|}
\hline & \begin{tabular}{ll} 
the cap and the liner: & \multicolumn{1}{c}{ MM. $(\mathrm{DE} \% / 100 \%$} \\
$\mathrm{Q}_{\mathrm{c}}=\mathrm{Q}_{\mathrm{res}} /\left[\left(\mathrm{d}_{c} / \mathrm{K}_{\mathrm{c}} \cdot \mathrm{A}_{\mathrm{c}}\right) \cdot\left(\mathrm{K}_{\mathrm{l}} \cdot \mathrm{A}_{\mathrm{l}} / \mathrm{d}_{\mathrm{l}}\right)+1\right]$ & 3. Migration of gas: \\
$\mathrm{Q}_{1}=\mathrm{Q}_{\mathrm{res}} /\left[\left(\mathrm{d}_{1} /\left(\mathrm{K}_{\mathrm{l}} \cdot \mathrm{A}_{\mathrm{l}}\right)\right) \cdot\left(\left(\mathrm{K}_{\mathrm{c}} \cdot \mathrm{A}_{c}\right) / \mathrm{d}_{c}\right)+1\right]$ & $\partial_{d} \partial_{\mathrm{t}}=\mathrm{D}_{\mathrm{L}}\left(\partial^{2} \mathrm{c} / \partial^{2} \mathrm{x}\right)-v\left(\partial_{d} \partial_{\mathrm{x}}\right)-\gamma \mathrm{c}$
\end{tabular} \\
\hline $\begin{array}{l}\text { Components } \\
\text { incorporated } \\
\text { with the } \\
\text { model }\end{array}$ & $\begin{array}{l}\text { GasSim is a computer model. It has been encoded using Micrsoft Visual } \\
\text { Basic and C++ programming languges. GasSim model has been developed } \\
\text { using the HELGA framework (Gregory et al., 1999), which was developed } \\
\text { for the Environment Agency, England. The Monte Carlo simulation technique } \\
\text { was used to model the uncertainty associated with many of the input } \\
\text { parameters. Environmental transport is simulated using (Gaussian plume) } \\
\text { model. GasSim is a steady state model. } \\
\text { Assumptions: } \\
\text { 1. GasSim determines the generation of methane gas, carbon dioxide and } \\
\text { hydrogen produced using multiphase levels of first order decay equations. } \\
\text { 2. Divided into } 4 \text { main modules: } \\
\text { - Source term } \\
\text { - Environmental transport and } \\
\text { 3. The methanogenic degradation of carbon is simulated by dividing the waste } \\
\text { streams into three waste fractions (rapid, moderate and slow). } \\
\text { 4. The model assumes that any LFG generated and not collected would be } \\
\text { emitted through the landfill cap or liner at a steady state. } \\
\text { 5. GasSim assumes that gas generated from an uncapped area, is not } \\
\text { collected, and would be released through the surface to the atmosphere } \\
\text { without methane oxidation. } \\
\text { Limitations: } \\
\text { 1. GasSim determines the quantity of trace gas generated by proportioning the } \\
\text { concentration of the trace gas species to the LFG generation rate. } \\
\text { 2. GasSim does not simulate: } \\
\text { or collapse of mine workings. } \\
\text { - The movement of landfill leachate or LFG dissolved in water. }\end{array}$ \\
\hline
\end{tabular}




\begin{tabular}{|c|c|}
\hline & $\begin{array}{l}\text { - Acute events associated with sudden drops in atmospheric pressure resulting } \\
\text { in lateral migration e.g asphyxiation and acute health effects by exposure to } \\
\text { VOCs. } \\
\text { - There is no biological oxidation of methane gas, dispersion, retardation or } \\
\text { other attenuation/reaction processes that reduce the concentration of any gas } \\
\text { as it moves through the ground. This will result in an overly conservative } \\
\text { approach. } \\
\text { - GasSim does not simulate the migration of dissolved gases. }\end{array}$ \\
\hline Model name & $\begin{array}{l}\text { LQM Model developed from the Department of Environment Food and } \\
\text { Rural Affairs (DEFRA), UK, } 2003\end{array}$ \\
\hline Team & $\begin{array}{l}\text { LQM (Land Quality Management Limited) and ERM (Environmental } \\
\text { Resource Management), UK }\end{array}$ \\
\hline $\begin{array}{l}\text { Equations } \\
\text { used }\end{array}$ & 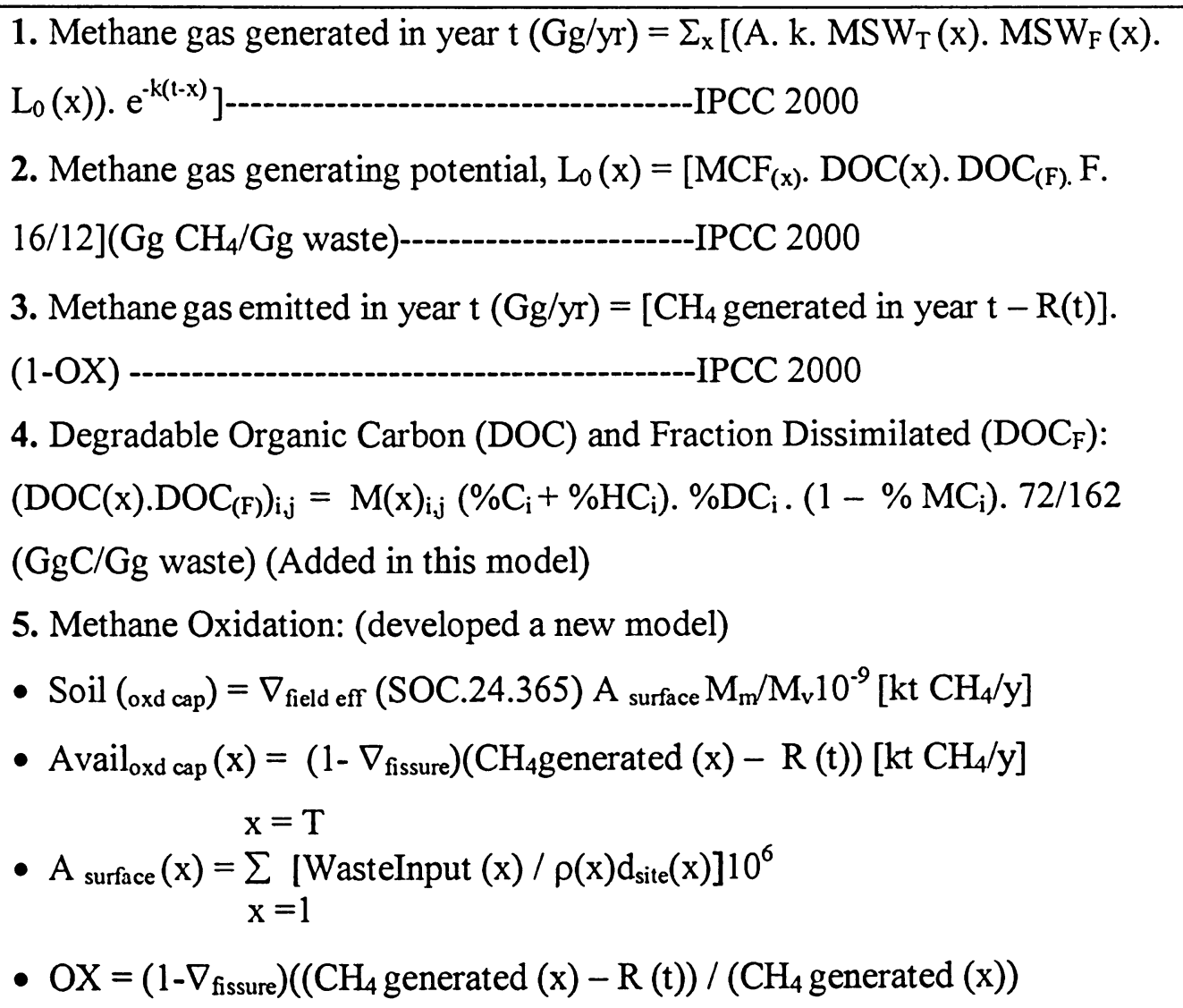 \\
\hline $\begin{array}{l}\text { Components } \\
\text { incorporated } \\
\text { with the }\end{array}$ & $\begin{array}{l}\text { Assumptions: } \\
\text { 1. Methane gas generation rate was calculated considering the solid waste } \\
\text { type as slowly degradable, moderately degradable, and rapidly degradable }\end{array}$ \\
\hline
\end{tabular}




\begin{tabular}{|l|l|}
\hline model & $\begin{array}{l}\text { waste (Brown et al. (1999)). } \\
\text { 2. Methane Correction Factor: } \\
\mathrm{MCF}_{(\mathrm{x})}=1.0 \text { (managed solid waste disposal site) } \\
=<1 \text { (unmanaged solid waste disposal site) }\end{array}$ \\
& $\begin{array}{l}\text { 3. Fraction of Methane in LFG: } \\
\mathrm{F}=0.5 \text { (Engineered design) } \\
\mathrm{F}=0.3 \text { (Un Engineered design) } \\
\text { 4. Commercial and Industrial (C\&I) waste streams were introduced alongside } \\
\text { municipal solid waste (MSW) in this model. }\end{array}$ \\
\end{tabular}

Table 4 Other models summery on landfill gas generation and emissions.

\begin{tabular}{|c|c|}
\hline Iodel name & jEN) model \\
\hline Team & University of Central Florida, USA \\
\hline $\begin{array}{l}\text { Equations } \\
\text { used }\end{array}$ & 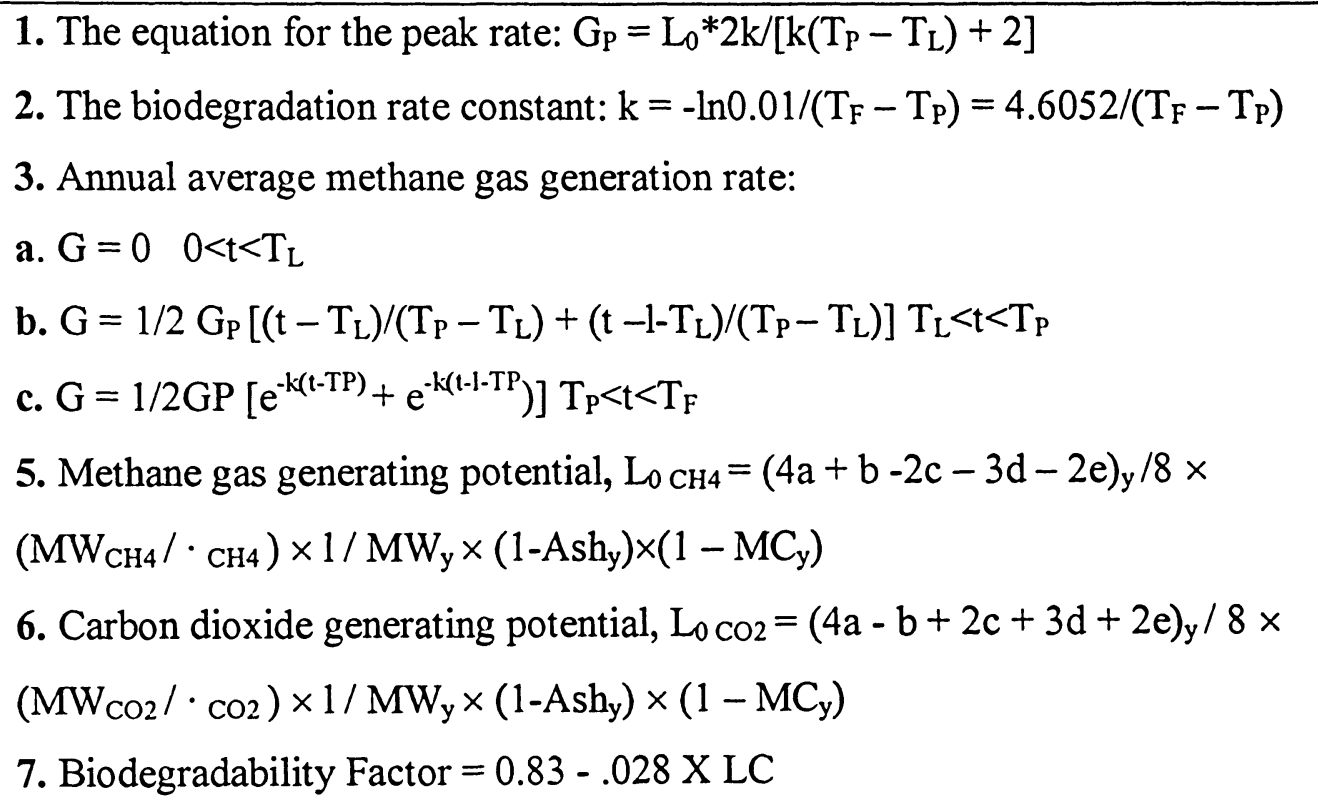 \\
\hline $\begin{array}{l}\text { Components } \\
\text { incorporated } \\
\text { with the } \\
\text { model }\end{array}$ & $\begin{array}{l}\text { This is a user-friendly computer programmed model developed at UCF } \\
\text { (University of Central Florida) to predict methane gas flux from any Florida } \\
\text { landfill. } \\
\text { Assumptions: } \\
\text { 1. Division of biodegradable solid waste into eleven categories were } \\
\text { considered. }\end{array}$ \\
\hline
\end{tabular}




\begin{tabular}{|c|c|}
\hline & $\begin{array}{l}\text { 2. Three moisture classifications - wet, moderate, and dry were adopted. } \\
\text { 3. Three biodegradability rates - rapid, moderate, and slow were simulated. } \\
\text { 4. LFGGEN can calculate trace gas annual average flux rates and mass } \\
\text { generation. } \\
\text { 5. The model assumes that the trace gas is being generated in a constant } \\
\text { proportion to the landfill gas. } \\
\text { 6. The model assumes that the gas that is generated in the landfill would } \\
\text { transported out. } \\
\text { 7. Used to estimate global impacts, methane gas recovery potential, provide } \\
\text { input to a microscale air quality model. } \\
\text { Limitation: } \\
\text { 1. The same equations for methane gas generation rate are used for carbon } \\
\text { dioxide gas generation rate. }\end{array}$ \\
\hline Model name & Mexico landfill gas model \\
\hline Team & $\begin{array}{l}\text { SCS Engineers under contract to the U.S. EPA's, Landfill Methane Outreach } \\
\text { Program (LMOP), } 2003\end{array}$ \\
\hline $\begin{array}{l}\text { Equations } \\
\text { used }\end{array}$ & $\begin{array}{l}n \\
Q_{M}=\sum 2 k L_{o} M_{i}\left(e^{-k t}{ }_{i}\right) \\
\text { Where } \\
n \\
\sum_{i=1}=\text { sum from opening year }(i=1) \text { through year of projection, } n \\
Q_{M}=\text { maximum expected } L F G \text { generation flow rate }(\mathrm{m} / \mathrm{yr}) \\
\mathrm{k}=\text { methane gas generation rate constant }(1 / \mathrm{yr}) \\
\mathrm{L}_{\mathrm{o}}=\text { methane gas generation potential }\left(\mathrm{m}^{3} / \mathrm{Mg}\right) \\
\mathrm{M}_{\mathrm{i}}=\text { mass of solid waste disposed in the } \mathrm{i}^{\text {th }} \text { year }(\mathrm{Mg}) \\
\mathrm{t}_{\mathrm{i}}=\text { age of the waste disposed in the } \mathrm{i}^{\text {th }} \text { year (years) }\end{array}$ \\
\hline $\begin{array}{l}\text { Components } \\
\text { incorporated } \\
\text { with the } \\
\text { model }\end{array}$ & $\begin{array}{l}\text { The Mexico LFG Model is an Excel spreadsheet based on a first order decay } \\
\text { equation developed with the help of US EPA's LandGEM model. } \\
\text { Mexico LFG model calculates the maximum expected LFG generation and } \\
\text { recovery potential. }\end{array}$ \\
\hline
\end{tabular}




\begin{tabular}{|c|c|}
\hline & $\begin{array}{l}\text { Factors considered in model: } \\
\text { - Amount of waste in place, • Methane gas generation rate }(\mathrm{k}) \text {, and } \\
\text { Assumptions: } \\
\text { 1. Time lag between the placement of waste and LFG generation is assumed } \\
\text { to be one-year. } \\
\text { 2. For each unit of waste, after one year the model assumes that LFG } \\
\text { generation decreases exponentially as the organic fraction of waste is } \\
\text { consumed. } \\
\text { 3. Total landfill gas generation is estimated by doubling methane gas } \\
\text { generation (the landfill gas is assumed to be half methane gas and half carbon } \\
\text { dioxide). } \\
\text { 4. It estimates the energy content of generated landfill gas in Giga joules per } \\
\text { year (G J/yr). } \\
\text { 5. The model provides the default values for } k \text { and } L_{0} \text {. } \\
\text { Limitation: } \\
\text { 1. Modeling landfill gas generation and recovery accurately is difficult due to } \\
\text { the limitations in available information for inputs data to the model. }\end{array}$ \\
\hline Model Name & The Scholl-Canyon model \\
\hline Team & USA \\
\hline $\begin{array}{l}\text { Equations } \\
\text { used }\end{array}$ & $\begin{array}{l}\text { 1. } \mathrm{CH}_{4} \text { generation rate at time } \mathrm{t} \text { : } \\
\mathrm{Q}_{\mathrm{CH} 4}=\mathrm{L}_{0} * \mathrm{R}\left(\mathrm{e}^{-\mathrm{kc}}-\mathrm{e}^{-\mathrm{kt}}\right) \\
\text { 2. } \mathrm{Q}=2^{*} \mathrm{k} * \mathrm{~L}_{0} * \mathrm{R}\left(\mathrm{e}^{-\mathrm{k}(\mathrm{t}-\mathrm{lag})}\right) \text { (The refined Scholl Canyon Model equation) }\end{array}$ \\
\hline $\begin{array}{l}\text { Components } \\
\text { incorporated } \\
\text { with the } \\
\text { model }\end{array}$ & $\begin{array}{l}\text { Scholl Canyon model is first order decay model. } \\
\text { Assumptions: } \\
\text { 1. The Scholl Canyon Model assumes that methane generation is a function of } \\
\text { first-order kinetics. } \\
\text { 2. This model ignores the first two stages of bacterial activity and is simply } \\
\text { based on the observed characteristics of substrate-limited bacterial growth. } \\
\text { 3. The gas production rate is assumed to be at its peak rate based on initial }\end{array}$ \\
\hline
\end{tabular}




\begin{tabular}{|l|l|}
\hline placement after a negligible lag time. During that time anaerobic conditions \\
are established and decreases exponentially (first-order decay) as the organic \\
content of the waste is consumed. \\
4. The model is dependent on the following factors that affect biodegradation \\
rates: \\
- Age of waste, \\
- Moisture content. \\
- Average annual placement rates are used \\
5. The model uses two adjustable variables namely $L_{0}$ and $k$. \\
Limitation: \\
1. The model is impractical for use global scale where site-specific data are \\
not available.
\end{tabular}

Table 5 Different types of waste categories used for the analysis of the RLFGM model

\begin{tabular}{|l|l|}
\hline Degradability & Waste Fraction \\
\hline Rapid (RDO) & Paper and Card \\
\hline & Textiles \\
\hline & Misc. Combustible (plus non inert) \\
\hline & Composted putrescible \\
\hline Moderate (MDO) & Ferrous Metal \\
\hline & Non Ferrous Metal \\
\hline Slow (SDO) & Dense Plastics \\
\hline & Misc. Non Combustible (Plus inert fines) \\
\hline & Glass \\
\hline
\end{tabular}

Table 6 MSW waste (Mt) used in the simulation of RLFGM model (Data Source Barlaz et al. (1997), Bellingham et al. (1994), environment agency UK 2002a, department of the environment UK, $1994 \mathrm{a}, \mathrm{b}$ and some of them are defined by the developer). The table shows the input data for year 1995 to year 2000 years. The simulation was performed for thirty years. 


\begin{tabular}{|c|c|c|c|c|c|c|c|c|}
\hline $\begin{array}{l}\text { Waste Acceptance } \\
\text { Year }\end{array}$ & 2000 & 1999 & 1998 & 1997 & 1996 & 1995 & Year & \\
\hline Acceptance Rates, Mt/yr & 8.27 & 8.65 & 8.30 & 8.36 & 7.92 & 7.63 & \multirow{5}{*}{$\begin{array}{l}\text { Paper } \\
\text { and } \\
\text { Card } \\
\text { RDO }\end{array}$} & \multirow{15}{*}{$\begin{array}{l}\text { Waste } \\
\text { Category }\end{array}$} \\
\hline$\% \mathrm{MC}_{\mathrm{i}}$ & 31.35 & 31.98 & 31.41 & 31.60 & 31.00 & 30.00 & & \\
\hline$\% \mathrm{C}_{\mathrm{i}}(\% \mathrm{DW})$ & 61.32 & 62.00 & 61.312 & 61.36 & 61.30 & 61.20 & & \\
\hline$\% \mathrm{HC}_{\mathrm{i}}(\% \mathrm{DW})$ & 9.55 & 9.78 & 9.66 & 9.566 & 9.12 & 9.10 & & \\
\hline$\% \mathrm{DC}_{\mathrm{i}}$ & 61.89 & 62.10 & 61.90 & 61.92 & 61.81 & 61.80 & & \\
\hline Acceptance Rates, Mt/yr & 0.58 & 0.59 & 0.54 & 0.52 & 0.50 & 0.48 & \multirow{5}{*}{$\begin{array}{l}\text { Textiles } \\
- \text { RDO }\end{array}$} & \\
\hline$\% \mathrm{MC}_{\mathrm{i}}$ & 26.94 & 26.98 & 26.674 & 26.60 & 26.00 & 25.00 & & \\
\hline$\% \mathrm{C}_{\mathrm{i}}(\% \mathrm{DW})$ & 21.86 & 22.00 & 21.00 & 20.876 & 20.50 & 20.00 & & \\
\hline$\% \mathrm{HC}_{\mathrm{i}}(\% \mathrm{DW})$ & 20.90 & 21.00 & 20.756 & 20.675 & 20.50 & 20.00 & & \\
\hline$\% \mathrm{DC}_{\mathrm{i}}$ & 50.58 & 50.59 & 50.253 & 50.253 & 50.10 & 50.00 & & \\
\hline Acceptance Rates, Mt/yr & 2.46 & 2.16 & 2.08 & 2.09 & 1.98 & 1.91 & \multirow{5}{*}{$\begin{array}{l}\text { Misc. } \\
\text { Combus } \\
\text { t-ible } \\
\text { (Plus } \\
\text { Non } \\
\text { Inert } \\
\text { Fines)- } \\
\text { RDO }\end{array}$} & \\
\hline$\% \mathrm{MC}_{\mathrm{i}}$ & 21.94 & 21.78 & 21.14 & 21.20 & 21.00 & 20.00 & & \\
\hline$\% \mathrm{C}_{\mathrm{i}}(\% \mathrm{DW})$ & 26.78 & 26.00 & 25.75 & 25.84 & 25.50 & 25.00 & & \\
\hline$\% \mathrm{HC}_{\mathrm{i}}(\% \mathrm{DW})$ & 26.12 & 25.89 & 25.56 & 25.67 & 25.40 & 25.00 & & \\
\hline$\% \mathrm{DC}_{\mathrm{i}}$ & 51.345 & 51.00 & 50.786 & 50.786 & 50.32 & 30.00 & & \\
\hline
\end{tabular}




\begin{tabular}{|c|c|c|c|c|c|c|c|c|}
\hline $\begin{array}{l}\text { Waste Acceptance } \\
\text { Year }\end{array}$ & 2000 & 1999 & 1998 & 1997 & 1996 & 1995 & Year & \\
\hline Acceptance Rates, Mt/yr & 5.53 & 5.68 & 5.45 & 5.49 & 5.20 & 5.00 & \multirow{5}{*}{$\begin{array}{l}\text { Composted } \\
\text { Putrescible } \\
\text { - RDO }\end{array}$} & \multirow{15}{*}{$\begin{array}{l}\text { Waste } \\
\text { Category }\end{array}$} \\
\hline$\% \mathrm{MC}_{\mathrm{i}}$ & 30.96 & 31.00 & 30.82 & 30.90 & 30.60 & 30.00 & & \\
\hline$\% \mathrm{C}_{\mathrm{i}}(\% \mathrm{DW})$ & 0.745 & 0.823 & 0.698 & 0.712 & 0.712 & 0.700 & & \\
\hline$\% \mathrm{HC}_{\mathrm{i}}(\% \mathrm{DW})$ & 0.823 & 0.845 & 0.717 & 0.720 & 0.700 & 0.700 & & \\
\hline$\% \mathrm{DC}_{\mathrm{i}}$ & 57.95 & 58.10 & 57.83 & 57.83 & 57.00 & 57.00 & & \\
\hline Acceptance Rates, Mt/yr & 1.38 & 1.48 & 1.56 & 1.57 & 1.49 & 1.43 & \multirow{5}{*}{$\begin{array}{l}\text { Ferrous Metal } \\
\text { - MDO }\end{array}$} & \\
\hline$\% \mathrm{MC}_{\mathrm{i}}$ & 5.10 & 4.99 & 5.20 & 5.21 & 5.00 & 5.00 & & \\
\hline$\% \mathrm{C}_{\mathrm{i}}(\% \mathrm{DW})$ & 0.00 & 0.00 & 0.00 & 0.00 & 0.00 & 0.00 & & \\
\hline$\% \mathrm{HC}_{\mathrm{i}}(\% \mathrm{DW})$ & 0.00 & 0.00 & 0.00 & 0.00 & 0.00 & 0.00 & & \\
\hline$\% \mathrm{DC}_{\mathrm{i}}$ & 0.00 & 0.00 & 0.00 & 0.00 & 0.00 & 0.00 & & \\
\hline Acceptance Rates, Mt/yr & 0.57 & 0.57 & 0.52 & 0.52 & 0.50 & 0.48 & \multirow{5}{*}{$\begin{array}{l}\text { Non Ferrous } \\
\text { Metal - MDO }\end{array}$} & \\
\hline$\% \mathrm{MC}_{\mathrm{i}}$ & 11.56 & 11.50 & 10.76 & 10.78 & 10.50 & 10.00 & & \\
\hline$\% \mathrm{C}_{\mathrm{i}}(\% \mathrm{DW})$ & 0.00 & 0.00 & 0.00 & 0.00 & 0.00 & 0.00 & & \\
\hline$\% \mathrm{HC}_{\mathrm{i}}(\% \mathrm{DW})$ & 0.00 & 0.00 & 0.00 & 0.00 & 0.00 & 0.00 & & \\
\hline$\% \mathrm{DC}_{\mathrm{i}}$ & 0.00 & 0.00 & 0.00 & 0.00 & 0.00 & 0.00 & & \\
\hline
\end{tabular}




\begin{tabular}{|c|c|c|c|c|c|c|c|c|}
\hline $\begin{array}{l}\text { Waste Acceptance } \\
\text { Year }\end{array}$ & 2000 & 1999 & 1998 & 1997 & 1996 & 1995 & Year & \\
\hline Acceptance Rates, Mt/yr & 3.35 & 2.97 & 2.85 & 2.88 & 2.72 & 2.62 & \multirow{5}{*}{$\begin{array}{l}\text { Dense } \\
\text { Plastics } \\
\text {-SDO }\end{array}$} & \multirow{15}{*}{$\begin{array}{l}\text { Waste } \\
\text { Category }\end{array}$} \\
\hline$\% \mathrm{MC}_{\mathrm{i}}$ & 6.50 & 5.95 & 5.76 & 5.80 & 5.00 & 5.00 & & \\
\hline$\% \mathrm{C}_{\mathrm{i}}(\% \mathrm{DW})$ & 0.00 & 0.00 & 0.00 & 0.00 & 0.00 & 0.00 & & \\
\hline$\% \mathrm{HC}_{\mathrm{i}}(\% \mathrm{DW})$ & 0.00 & 0.00 & 0.00 & 0.00 & 0.00 & 0.00 & & \\
\hline$\% \mathrm{DC}_{\mathrm{i}}$ & 0.00 & 0.00 & 0.00 & 0.00 & 0.00 & 0.00 & & \\
\hline Acceptance Rates, Mt/yr & 2.40 & 2.43 & 2.33 & 2.35 & 2.34 & 2.14 & \multirow{5}{*}{$\begin{array}{l}\text { Misc. } \\
\text { Non } \\
\text { Combus } \\
\text { tible } \\
\text { Plus } \\
\text { Inert } \\
\text { Fines - } \\
\text { SDO }\end{array}$} & \\
\hline$\% \mathrm{MC}_{\mathrm{i}}$ & 5.29 & 5.33 & 5.02 & 5.05 & 5.00 & 5.00 & & \\
\hline$\% \mathrm{C}_{\mathrm{i}}(\% \mathrm{DW})$ & 0.00 & 0.00 & 0.00 & 0.00 & 0.00 & 0.00 & & \\
\hline$\% \mathrm{HC}_{\mathrm{i}}(\% \mathrm{DW})$ & 0.00 & 0.00 & 0.00 & 0.00 & 0.00 & 0.00 & & \\
\hline$\% \mathrm{DC}_{\mathrm{i}}$ & 0.00 & 0.00 & 0.00 & 0.00 & 0.00 & 0.00 & & \\
\hline Acceptance Rates, Mt/yr & 2.43 & 2.33 & 2.34 & 2.35 & 2.23 & 2.14 & \multirow{5}{*}{$\begin{array}{l}\text { Glass - } \\
\text { SDO }\end{array}$} & \\
\hline$\% \mathrm{MC}_{\mathrm{i}}$ & 5.240 & 5.019 & 5.019 & 5.018 & 5.000 & 5.000 & & \\
\hline$\% \mathrm{C}_{\mathrm{i}}(\% \mathrm{DW})$ & 0.00 & 0.00 & 0.00 & 0.00 & 0.00 & 0.00 & & \\
\hline$\% \mathrm{HC}_{\mathrm{i}}(\% \mathrm{DW})$ & 0.00 & 0.00 & 0.00 & 0.00 & 0.00 & 0.00 & & \\
\hline$\% \mathrm{DC}_{\mathrm{i}}$ & 0.00 & 0.00 & 0.00 & 0.00 & 0.00 & 0.00 & & \\
\hline
\end{tabular}


Table 7 Waste degradation rate constants

\begin{tabular}{|c|c|c|c|c|c|c|}
\hline & \multicolumn{6}{|c|}{$\begin{array}{l}\text { Rate constant, } k \text { (per year) also expressed as a half life, } t_{1 / 2} \\
\text { (years) }\end{array}$} \\
\hline & \multicolumn{2}{|c|}{$\begin{array}{l}\text { Manely et al. (1990a; } \\
\text { 1990b) }\end{array}$} & \multicolumn{2}{|c|}{ Brown et al. (1999) } & \multicolumn{2}{|c|}{$\begin{array}{l}\text { GasSim } \\
\text { (Environmental } \\
\text { Agency 2002a), } \\
\text { RLFGM used } \\
\text { these values for } \\
\text { the implemen- } \\
\text {-tation purpose }\end{array}$} \\
\hline & $\mathrm{K}$ & $t_{1 / 2}$ & $\mathrm{~K}$ & $t_{1 / 2}$ & $\mathrm{~K}$ & $\overline{t_{1 / 2}}$ \\
\hline $\begin{array}{l}\text { Rapidly Degradable } \\
\text { Organic }\end{array}$ & 0.69 & 1 & 0.185 & 3.75 & 0.116 & 6 \\
\hline $\begin{array}{l}\text { Moderately Degradable } \\
\text { Organic }\end{array}$ & 0.14 & 5 & 0.1 & 6.9 & 0.076 & 9 \\
\hline $\begin{array}{l}\text { Slowly Degradable } \\
\text { Organic }\end{array}$ & 0.05 & $\sim 15$ & 0.05 & $\sim 15$ & 0.046 & 15 \\
\hline
\end{tabular}

Table 8 SWDS (Solid Waste Disposal Sites) classification and methane correction factors

\begin{tabular}{|l|l|}
\hline Type of Site & Methane Correction Factor \\
\hline Managed & 1 \\
\hline Unmanaged (deep, $\geq 5 \mathrm{~m}$ waste) & 0.8 \\
\hline Unmanaged (shallow, $<5 \mathrm{~mm}$ waste) & 0.4 \\
\hline Default Value (Uncategorized SWDS) & 0.6 \\
\hline
\end{tabular}

Table 9 Typical landfill gas compositions at methanogenic phase

\begin{tabular}{|l|l|}
\hline Gas Component & Component Content (\% by volume) \\
\hline Methane & $45.00-60.00 \%$ \\
\hline Carbon Dioxide & $40.00-60.00 \%$ \\
\hline Nitrogen & $2.00-5.00 \%$ \\
\hline Oxygen & $0.10-1.0 \%$ \\
\hline Ammonia & $0.10-1.0 \%$ \\
\hline Hydrogen & $0.00-0.20 \%$ \\
\hline
\end{tabular}


Table 10 Calculated DOC(x).DOC $\mathrm{F}$ values based on data input in Table 6. Measured unit Gg $\mathrm{C} / \mathrm{Gg}$ waste

\begin{tabular}{|c|c|c|c|c|c|c|c|c|c|}
\hline$\stackrel{ \pm}{\check{\Xi}}$ & 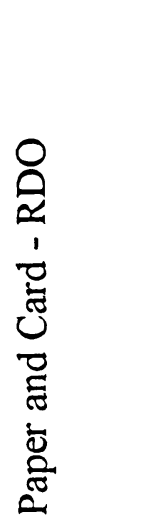 & 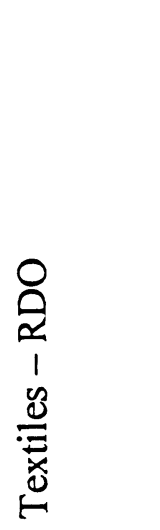 & 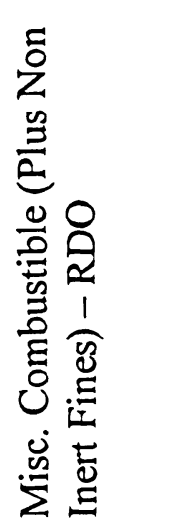 & 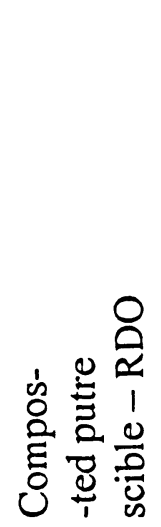 & 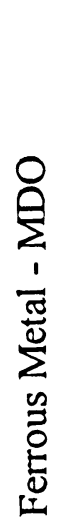 & 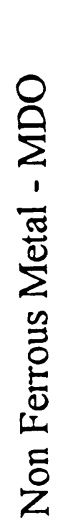 & 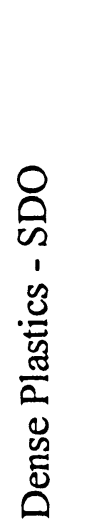 & 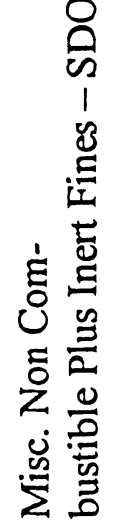 & $\begin{array}{l}0 \\
\text { क } \\
1 \\
\frac{3}{0}\end{array}$ \\
\hline 1995 & 0.0010313 & 0.000032 & 0.0001698 & $1.241 \mathrm{E}-05$ & 0.00 & 0.00 & 0.00 & 0.00 & 0.00 \\
\hline 1996 & 0.0010572 & $3.378 \mathrm{E}-05$ & 0.0001781 & $1.291 \mathrm{E}-05$ & 0.00 & 0.00 & 0.00 & 0.00 & 0.00 \\
\hline 1997 & 0.0011161 & $3.542 \mathrm{E}-05$ & 0.0001915 & $1.397 \mathrm{E}-05$ & 0.00 & 0.00 & 0.00 & 0.00 & 0.00 \\
\hline 1998 & 0.0011116 & $3.693 \mathrm{E}-05$ & 0.0001900 & $1.373 \mathrm{E}-05$ & 0.00 & 0.00 & 0.00 & 0.00 & 0.00 \\
\hline 1999 & 0.0011656 & $4.165 \mathrm{E}-05$ & 0.0001987 & $1.688 \mathrm{E}-05$ & 0.00 & 0.00 & 0.00 & 0.00 & 0.00 \\
\hline 2000 & 0.0011067 & $4.073 \mathrm{E}-05$ & 0.0002318 & $1.542 \mathrm{E}-05$ & 0.00 & 0.00 & 0.00 & 0.00 & 0.00 \\
\hline 2001 & 0.0010493 & $3.990 \mathrm{E}-05$ & 0.0002293 & $1.340 \mathrm{E}-05$ & 0.00 & 0.00 & 0.00 & 0.00 & 0.00 \\
\hline 2002 & 0.0009935 & $3.859 \mathrm{E}-05$ & 0.0002266 & $1.105 \mathrm{E}-05$ & 0.00 & 0.00 & 0.00 & 0.00 & 0.00 \\
\hline 2003 & 0.0009306 & $3.680 \mathrm{E}-05$ & 0.0002233 & $1.121 \mathrm{E}-05$ & 0.00 & 0.00 & 0.00 & 0.00 & 0.00 \\
\hline 2004 & 0.0008346 & $3.771 \mathrm{E}-05$ & 0.0002200 & $9.806 \mathrm{E}-06$ & 0.00 & 0.00 & 0.00 & 0.00 & 0.00 \\
\hline 2005 & 0.0008264 & $3.851 \mathrm{E}-05$ & 0.0002242 & $1.029 \mathrm{E}-05$ & 0.00 & 0.00 & 0.00 & 0.00 & 0.00 \\
\hline 2006 & 0.0008229 & $3.860 \mathrm{E}-05$ & 0.0002256 & $1.149 \mathrm{E}-05$ & 0.00 & 0.00 & 0.00 & 0.00 & 0.00 \\
\hline 2007 & 0.0008210 & $3.949 \mathrm{E}-05$ & 0.0002295 & $1.096 \mathrm{E}-05$ & 0.00 & 0.00 & 0.00 & 0.00 & 0.00 \\
\hline 2008 & 0.0008039 & $3.940 \mathrm{E}-05$ & 0.0002384 & $1.044 \mathrm{E}-05$ & 0.00 & 0.00 & 0.00 & 0.00 & 0.00 \\
\hline 2009 & 0.0007795 & $3.454 \mathrm{E}-05$ & 0.0002388 & $9.845 \mathrm{E}-06$ & 0.00 & 0.00 & 0.00 & 0.00 & 0.00 \\
\hline 2000 & 0.0006988 & $3.247 \mathrm{E}-05$ & 0.0002167 & $8.706 \mathrm{E}-06$ & 0.00 & 0.00 & 0.00 & 0.00 & 0.00 \\
\hline 2011 & 0.0006079 & $2.716 \mathrm{E}-05$ & 0.0001925 & $7.123 \mathrm{E}-06$ & 0.00 & 0.00 & 0.00 & 0.00 & 0.00 \\
\hline 2012 & 0.0005252 & $2.216 \mathrm{E}-05$ & 0.0001638 & $5.901 \mathrm{E}-06$ & 0.00 & 0.00 & 0.00 & 0.00 & 0.00 \\
\hline 2013 & 0.0004440 & $1.819 \mathrm{E}-05$ & 0.0001386 & $4.450 \mathrm{E}-06$ & 0.00 & 0.00 & 0.00 & 0.00 & 0.00 \\
\hline 2014 & 0.0003683 & $1.718 \mathrm{E}-05$ & 0.0001351 & $3.381 \mathrm{E}-06$ & 0.00 & 0.00 & 0.00 & 0.00 & 0.00 \\
\hline 2015 & 0.0003511 & $1.692 \mathrm{E}-05$ & 0.0001125 & $3.035 \mathrm{E}-06$ & 0.00 & 0.00 & 0.00 & 0.00 & 0.00 \\
\hline 2016 & 0.0003406 & $1.691 \mathrm{E}-05$ & 0.0001107 & $2.856 \mathrm{E}-06$ & 0.00 & 0.00 & 0.00 & 0.00 & 0.00 \\
\hline 2017 & 0.0003286 & $1.624 \mathrm{E}-05$ & 0.0001086 & $2.629 \mathrm{E}-06$ & 0.00 & 0.00 & 0.00 & 0.00 & 0.00 \\
\hline 2018 & 0.0003153 & $1.555 \mathrm{E}-05$ & 0.0001055 & $2.302 \mathrm{E}-06$ & 0.00 & 0.00 & 0.00 & 0.00 & 0.00 \\
\hline 2019 & 0.0003032 & $1.551 \mathrm{E}-05$ & 0.0001034 & $1.905 \mathrm{E}-06$ & 0.00 & 0.00 & 0.00 & 0.00 & 0.00 \\
\hline 2020 & 0.0002916 & $1.545 \mathrm{E}-05$ & 0.0001005 & $1.662 \mathrm{E}-06$ & 0.00 & 0.00 & 0.00 & 0.00 & 0.00 \\
\hline 2021 & 0.0002760 & $1.479 \mathrm{E}-05$ & $9.733 \mathrm{E}-05$ & $1.542 \mathrm{E}-06$ & 0.00 & 0.00 & 0.00 & 0.00 & 0.00 \\
\hline 2022 & 0.0002623 & $1.414 \mathrm{E}-05$ & $9.199 \mathrm{E}-05$ & $1.336 \mathrm{E}-06$ & 0.00 & 0.00 & 0.00 & 0.00 & 0.00 \\
\hline 2023 & 0.0002471 & $1.347 \mathrm{E}-05$ & $8.880 \mathrm{E}-05$ & $1.168 \mathrm{E}-06$ & 0.00 & 0.00 & 0.00 & 0.00 & 0.00 \\
\hline 2024 & 0.0002213 & $1.279 \mathrm{E}-05$ & $8.439 \mathrm{E}-05$ & $7.239 \mathrm{E}-07$ & 0.00 & 0.00 & 0.00 & 0.00 & 0.00 \\
\hline 2025 & 0.0002060 & $1.178 \mathrm{E}-05$ & $7.515 \mathrm{E}-05$ & $3.523 \mathrm{E}-07$ & 0.00 & 0.00 & 0.00 & 0.00 & 0.00 \\
\hline
\end{tabular}


Table 11 Sample output of RLFGM model implementation for methane gas generating potential $\left(\mathrm{L}_{0}\right)$. Measured unit $\mathrm{Gg} \mathrm{CH}_{4} / \mathrm{Gg}$ Waste

\begin{tabular}{|c|c|c|c|c|c|c|c|}
\hline Year & $\begin{array}{l}\mathrm{L}_{0}(\mathrm{x})- \\
\mathrm{RDO}\end{array}$ & $\begin{array}{l}\mathrm{L}_{0}(\mathrm{x})- \\
\mathrm{MDO}\end{array}$ & $\begin{array}{l}\mathrm{L}_{0}(\mathrm{x})- \\
\mathrm{SDO}\end{array}$ & Year & $\begin{array}{l}\mathrm{L}_{0}(\mathrm{x})- \\
\mathrm{RDO}\end{array}$ & $\begin{array}{l}\mathrm{L}_{0}(\mathrm{x})- \\
\mathrm{MDO}\end{array}$ & $\begin{array}{l}\mathrm{L}_{0}(\mathrm{x})- \\
\mathrm{SDO}\end{array}$ \\
\hline 1995 & 0.0008303 & 0.00 & 0.00 & 2011 & 0.0134700 & 0.00 & 0.00 \\
\hline 1996 & 0.0016849 & 0.00 & 0.00 & 2012 & 0.0139481 & 0.00 & 0.00 \\
\hline 1997 & 0.0025896 & 0.00 & 0.00 & 2013 & 0.0143516 & 0.00 & 0.00 \\
\hline 1998 & 0.0034911 & 0.00 & 0.00 & 2014 & 0.0147009 & 0.00 & 0.00 \\
\hline 1999 & 0.0044397 & 0.00 & 0.00 & 2015 & 0.0150233 & 0.00 & 0.00 \\
\hline 2000 & 0.0053695 & 0.00 & 0.00 & 2016 & 0.0153373 & 0.00 & 0.00 \\
\hline 2001 & 0.0062574 & 0.00 & 0.00 & 2017 & 0.0156414 & 0.00 & 0.00 \\
\hline 2002 & 0.0071039 & 0.00 & 0.00 & 2018 & 0.0159338 & 0.00 & 0.00 \\
\hline 2003 & 0.0079052 & 0.00 & 0.00 & 2019 & 0.0162165 & 0.00 & 0.00 \\
\hline 2004 & 0.0086399 & 0.00 & 0.00 & 2020 & 0.0164893 & 0.00 & 0.00 \\
\hline 2005 & 0.0093728 & 0.00 & 0.00 & 2021 & 0.0167491 & 0.00 & 0.00 \\
\hline 2006 & 0.0101052 & 0.00 & 0.00 & 2022 & 0.0169956 & 0.00 & 0.00 \\
\hline 2007 & 0.0108392 & 0.00 & 0.00 & 2023 & 0.0172293 & 0.00 & 0.00 \\
\hline 2008 & 0.0115673 & 0.00 & 0.00 & 2024 & 0.0174421 & 0.00 & 0.00 \\
\hline 2009 & 0.0122757 & 0.00 & 0.00 & 2025 & 0.0176376 & 0.00 & 0.00 \\
\hline 2010 & 0.0129135 & 0.00 & 0.00 & & & & \\
\hline
\end{tabular}

Table 12 Parameters from RLFGM model used for the simulation of the LandGEM model for the purpose of model verification

\begin{tabular}{|l|l|}
\hline Parameters & Value \\
\hline Methane Generating potential, $\mathrm{L}_{0}$ & $\mathrm{~L}_{0}=100 \mathrm{~m}^{3} / \mathrm{Mg}$ \\
\hline Methane content & $50 \%$ (by volume) $^{-1}$ \\
\hline $\begin{array}{l}\text { Methane generation rate constant, } \mathrm{k} \text { (for } \\
\text { RDO) }\end{array}$ & $0.116 \mathrm{year}^{-1}$ \\
\hline Solid waste components & From Table 6 (RDO component only) \\
\hline
\end{tabular}

Table 13 Methane gas emission rates from RLFGM model and LandGEM model.

\begin{tabular}{|c|c|c|c|c|c|c|c|}
\hline$\underset{\partial}{~}$ & 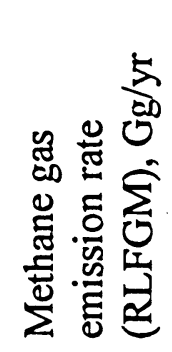 & 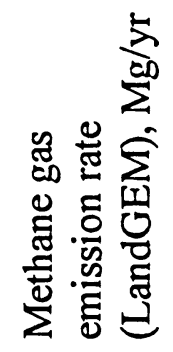 & 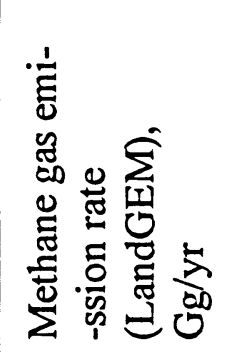 & 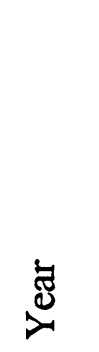 & 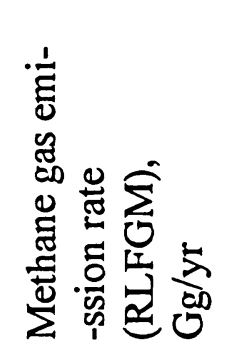 & 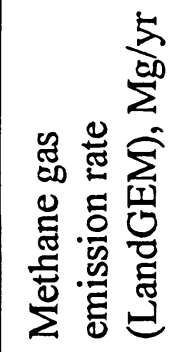 & 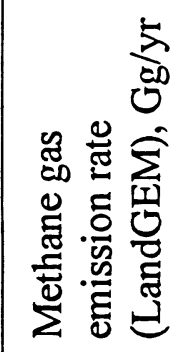 \\
\hline 1995 & $9.673 \mathrm{E}-10$ & 0 & 0 & 2011 & $1.325 \mathrm{E}-09$ & \begin{tabular}{|c|}
$8.037 \mathrm{E}-04$ \\
\end{tabular} & \begin{tabular}{|l|}
$8.037 \mathrm{E}-07$ \\
\end{tabular} \\
\hline 1996 & $1.886 \mathrm{E}-09$ & -04 & 1.10 & 2012 & $9.549 \mathrm{E}-10$ & \begin{tabular}{|c|}
$7.968 \mathrm{E}-04$ \\
\end{tabular} & \begin{tabular}{|l|}
$7.968 \mathrm{E}-07$ \\
\end{tabular} \\
\hline 1997 & $2.873 \mathrm{E}-09$ & $2.129 \mathrm{E}-04$ & \begin{tabular}{|l|}
$2.129 \mathrm{E}-07$ \\
\end{tabular} & 2013 & $6.543 \mathrm{E}-10$ & \begin{tabular}{|c|}
$7.813 \mathrm{E}-04$ \\
\end{tabular} & \begin{tabular}{|c|}
$7.813 \mathrm{E}-07$ \\
\end{tabular} \\
\hline 1998 & $3.411 \mathrm{E}-09$ & $3.106 \mathrm{E}-04$ & \begin{tabular}{|l|}
$3.106 \mathrm{E}-07$ \\
\end{tabular} & 2014 & $4.564 \mathrm{E}-10$ & \begin{tabular}{|c|}
$7.577 \mathrm{E}-04$ \\
\end{tabular} & \begin{tabular}{|c|}
$7.577 \mathrm{E}-07$ \\
\end{tabular} \\
\hline
\end{tabular}




\begin{tabular}{|l|l|l|l|l|l|l|l|}
\hline 1999 & $4.205 \mathrm{E}-09$ & $3.969 \mathrm{E}-04$ & $3.969 \mathrm{E}-07$ & 2015 & $3.725 \mathrm{E}-10$ & $7.290 \mathrm{E}-04$ & $7.290 \mathrm{E}-07$ \\
\hline 2000 & $4.403 \mathrm{E}-09$ & $4.789 \mathrm{E}-04$ & $4.789 \mathrm{E}-07$ & 2016 & $3.224 \mathrm{E}-10$ & $7.005 \mathrm{E}-04$ & $7.005 \mathrm{E}-07$ \\
\hline 2001 & $4.181 \mathrm{E}-09$ & $5.503 \mathrm{E}-04$ & $5.503 \mathrm{E}-07$ & 2017 & $2.775 \mathrm{E}-10$ & $6.739 \mathrm{E}-04$ & $6.739 \mathrm{E}-07$ \\
\hline 2002 & $3.827 \mathrm{E}-09$ & $6.084 \mathrm{E}-04$ & $6.084 \mathrm{E}-07$ & 2018 & $2.361 \mathrm{E}-10$ & $6.489 \mathrm{E}-04$ & $6.489 \mathrm{E}-07$ \\
\hline 2003 & $3.379 \mathrm{E}-09$ & $6.544 \mathrm{E}-04$ & $6.544 \mathrm{E}-07$ & 2019 & $2.028 \mathrm{E}-10$ & $6.251 \mathrm{E}-04$ & $6.251 \mathrm{E}-07$ \\
\hline 2004 & $2.909 \mathrm{E}-09$ & $6.891 \mathrm{E}-04$ & $6.891 \mathrm{E}-07$ & 2020 & $1.726 \mathrm{E}-10$ & $6.026 \mathrm{E}-04$ & $6.026 \mathrm{E}-07$ \\
\hline 2005 & $2.835 \mathrm{E}-09$ & $7.136 \mathrm{E}-04$ & $7.136 \mathrm{E}-07$ & 2021 & $1.445 \mathrm{E}-10$ & $5.812 \mathrm{E}-04$ & $5.812 \mathrm{E}-07$ \\
\hline 2006 & $2.726 \mathrm{E}-09$ & $7.359 \mathrm{E}-04$ & $7.359 \mathrm{E}-07$ & 2022 & $1.205 \mathrm{E}-10$ & $5.605 \mathrm{E}-04$ & $5.605 \mathrm{E}-07$ \\
\hline 2007 & $2.604 \mathrm{E}-09$ & $7.559 \mathrm{E}-04$ & $7.559 \mathrm{E}-07$ & 2023 & $1.004 \mathrm{E}-10$ & $5.403 \mathrm{E}-04$ & $5.403 \mathrm{E}-07$ \\
\hline 2008 & $2.460 \mathrm{E}-09$ & $7.736 \mathrm{E}-04$ & $7.736 \mathrm{E}-07$ & 2024 & $7.790 \mathrm{E}-11$ & $5.208 \mathrm{E}-04$ & $5.208 \mathrm{E}-07$ \\
\hline 2009 & $2.237 \mathrm{E}-09$ & $7.891 \mathrm{E}-04$ & $7.891 \mathrm{E}-07$ & 2025 & $5.581 \mathrm{E}-11$ & $5.005 \mathrm{E}-04$ & $5.005 \mathrm{E}-07$ \\
\hline 2010 & $1.771 \mathrm{E}-09$ & $8.011 \mathrm{E}-04$ & $8.011 \mathrm{E}-07$ & & &
\end{tabular}

Table 14 Comparison between RLFGM and LandGEM model

\begin{tabular}{|c|c|c|}
\hline Parameters & RLFGM model & LandGEM model \\
\hline Equations & $\begin{array}{l}\text { Model uses multilevel phases of } \\
\text { equations for the generation and } \\
\text { emission of methane gas from } \\
\text { landfills (equation } 2.1 \text { to } 2.4 \text { ) }\end{array}$ & $\begin{array}{l}\text { Model uses first order decay } \\
\text { equation (Appendix A, Table } 1 \text { ) }\end{array}$ \\
\hline Waste Category & $\begin{array}{l}\text { Model uses three types of waste } \\
\text { components as rapidly degradable, } \\
\text { moderately degradable and slowly } \\
\text { degradable organic making up nine } \\
\text { waste fractions as paper and } \\
\text { textiles, misc. combustible (plus } \\
\text { non inert), composted putrescible, } \\
\text { ferrous metal, non ferrous metal, } \\
\text { dense plastics, misc. non } \\
\text { combustible (plus inert fines) and } \\
\text { glass. }\end{array}$ & $\begin{array}{l}\text { All waste components having the } \\
\text { potential to generate methane gas } \\
\text { have been used. Only rapidly } \\
\text { degradable organic has been used } \\
\text { for the simulation purpose as } \\
\text { moderately degradable and slowly } \\
\text { degradable organic component } \\
\text { have very little possibility to } \\
\text { generate methane gas. }\end{array}$ \\
\hline $\begin{array}{l}\text { Methane gas generation rate } \\
\text { constants }\end{array}$ & $\begin{array}{l}\text { Three methane gas generation rate } \\
\text { constants were used as } 0.116 \text { (for } \\
\text { rapidly degradable organic), } 0.076 \\
\text { (for moderately degradable } \\
\text { organic) and } 0.046 \text { (for slowly } \\
\text { degradable organic) }\end{array}$ & $\begin{array}{l}\text { One methane gas generation rate } \\
\text { constant } 0.116 \text { year }^{-1} \text { from RLFGM } \\
\text { model was used for simulation } \\
\text { considering the fact that primarily } \\
\text { rapidly degradable organic } \\
\text { components generate methane gas. }\end{array}$ \\
\hline Methane gas generation potential & $\begin{array}{l}\text { The major difference between } \\
\text { RLFGM model and LandGEM } \\
\text { model is the calculation for the } \\
\text { methane generating potential }\left(\mathrm{L}_{0}\right)\end{array}$ & $\begin{array}{l}\text { The model uses } 100 \mathrm{~m}^{3} / \mathrm{Mg} \text { as the, } \\
\text { methane gencrating potential } \mathrm{L}_{0} \\
\text { value for the simulation purpose. }\end{array}$ \\
\hline
\end{tabular}




\begin{tabular}{|c|c|c|}
\hline & $\begin{array}{l}\text { which controls the methane gas } \\
\text { generation rate. For the } \\
\text { development of RLFGM model } \\
\text { equations } 2.1 \text { to } 2.3 \text { have been } \\
\text { used. The equations state that } \\
\text { methane gas generation potential is } \\
\text { based on the calculation of } \\
\text { DOC(x).DOC }(\mathrm{F}) \text { The term } \\
\text { degradable organic carbon (DOC) } \\
\text { and fraction dissimilated (DOC } \text { ) is } \\
\text { defined by moisture content, } \\
\text { cellulose, hemi-cellulose and } \\
\text { degradability fraction of cellulose } \\
\text { and hemi-cellulose of individual } \\
\text { waste category. The calculated } \\
\left.\text { methane generating potential ( } \mathrm{L}_{0}\right) \\
\text { have been used for the calculation } \\
\text { of methane gas generation in the } \\
\text { model. }\end{array}$ & \\
\hline Lignin component & $\begin{array}{l}\text { Lignin component is not } \\
\text { considered for the calculation of } \\
\left(\mathrm{DOC}(\mathrm{x}) \cdot \mathrm{DOC} \mathrm{C}_{\mathrm{F}}\right) \text { based on } \\
\text { comprehensive literature review. }\end{array}$ & $\begin{array}{l}\text { As the model does not go for the } \\
\text { calculation of methane generating } \\
\text { potential }\left(\mathrm{L}_{0}\right) \text { value, it is not } \\
\text { obvious that lignin component has } \\
\text { been considered for defining the } \\
\text { methane generating potential. }\end{array}$ \\
\hline Methane gas emission rate & $\begin{array}{l}\text { Methane gas emission rate output } \\
\text { was lower (Appendix A, Table 13) } \\
\text { than LandGEM output. }\end{array}$ & $\begin{array}{l}\text { Methane gas emission rate output } \\
\text { found higher compared to RLFGM } \\
\text { model output in the simulation } \\
\text { (Appendix A, Table 13). }\end{array}$ \\
\hline
\end{tabular}

